\title{
El rey va desnudo: realidad y retórica en el proyecto transformista de la $4 \mathrm{~T}$
}

\section{Humberto Márquez Covarrubias*}

Resumen. En México, el gobierno de la «cuarta transformación» habla profusamente de neoliberalismo, pero no de capitalismo; de corrupción, pero no de explotación; de megaproyectos, pero no de extractivismo; de democracia, pero no de oligarquía; de inseguridad, pero no de despojo. La tentativa de cambio derivada del triunfo electoral de AMLO abre el debate nacional sobre un desarrollo alternativo —incluso de alternativas al desarrollo. No obstante, la agenda política del obradorismo está hegemonizando los términos de discusión, encubriendo los problemas estructurales de México y reduciendo el enfoque al tema de corrupción y austeridad, dos perspectivas que no son contrarias a la estructura de poder que se dice contravenir. En sus primeros movimientos, el proyecto de gobierno de la «cuarta transformación» se orienta a una concentración del poder político mediante la reconstrucción del presidencialismo y la reestructuración burocrática, para luego incidir en la reproducción del capital mediante la continuidad de políticas macroeconómicas neoliberales y la ejecución de proyectos energéticos y de infraestructura con el concurso del gran capital. Además de afianzar una base social de apoyo con programas asistencialistas neopopulistas, piedra angular del discurso político. No obstante, se vislumbra un proceso fáustico que en sus propósitos anticipa una transformación de la vida nacional que está atrapada en proceso de modernización capitalista plagado de contradicciones, tensiones sociales y una crisis multidimensional económica, sanitaria y de seguridad. La expectativa de una transformación social sustantiva amerita, inevitablemente, afinar y profundizar el debate teórico y político sobre los grandes problemas nacionales y sus alternativas en un contexto global intrincado.

Palabras clave: capitalismo, neoliberalismo, Estado, transformación social, México.

* Docente investigador, Unidad Académica en Estudios del Desarrollo, Universidad Autónoma de Zacatecas (UAZ), México. 


\section{The king has no clothes: Reality and rhetoric in the transformative project of the $4 \mathrm{~T}$}

Abstract: In Mexico, the government of the «Fourth Transformation» talks frequently about neoliberalism, but not about capitalism; about corruption, but not exploitation; of megaprojects, but not about extractivism; of democracy, but not about the oligarchy; about insecurity, but not about displacement. The movement toward change founded on AMLO's electoral triumph opens the national debate regarding an alternative development —as well as alternatives to development. Regardless, the political agenda of obradorismo is hegemonizing the terms of the debate, obscuring the structural problems faced by Mexico and reducing the focus to the topics of corruption and austerity, two perspectives that are not in opposition to the power structure that it claims to oppose. In its initial acts, the project of the government of the «Fourth Transformation» looked to the concentration of political power through the rebuilding of presidencialismo and bureaucratic restructuring, later taking on the reproduction of capital through the continuation of neoliberal macroeconomic policies and the pursuit of energy and infrastructure projects with the aid of Big Capital. The government also consolidated its base of social support with neopopulist-assistencialist programs, a cornerstone of its political discourse. However, one can identify a Faustian process in which the proposals foresee a transformation of the country's development which is caught up in a process of capitalist modernization, plagued by contradictions social tensions and a multidimensional economic, health and security crisis. The hopes of a substantive social transformation deserve, inevitably, honing and deepening the theoretical and political debate about the enormous national challenges and their alternatives within a complex global context.

Keywords: capitalism, neoliberalism, State, social transformation, Mexico. 


\section{Ambigüedades contra el neoliberalismo: ¿gatopardismo?}

\section{El juego de la alternancia electoral y la izquierda posibilista}

El régimen de la alternancia electoral comenzó en 2000, con la cesión de la presidencia de la República al Partido Acción Nacional (PAN), para luego regresarla al Partido Revolucionario Institucional (PRI) y ahora concederla al partido Movimiento de Regeneración Nacional (Morena), emanado del Partido de la Revolución Democrática (PRD), en un juego de pase de estafeta del poder político, que ahora admite el tripartidismo (PRI-PAN-Morena). Las votaciones federales del 1 de julio de 2018 marcan un punto de quiebre en la vida política nacional, no sólo por el triunfo electoral de Andrés Manuel López Obrador (AMLO), a la postre representante de amplios sectores de izquierda y derecha, con un gran apoyo popular, ${ }^{1}$ sino por el clamor popular por un cambio de modelo económico-político en el país, lo cual significa el rechazo generalizado al neoliberalismo y la búsqueda de un nuevo paradigma de desarrollo nacional.

El significado histórico del triunfo de Morena en las elecciones presidenciales es la derrota del PRI luego de un tercer intento, en una versión reblandecida y atada a un sinnúmero de alianzas con los sectores oligárquicos que otrora denostaba discursivamente como la «mafia del poder», a la cual terminó por subsumir a su proyecto político. Las razones que explican ese resultado son: a) la crisis en el seno de la clase dominante; b) el logro

${ }^{1}$ En un país de 120 millones de habitantes, sólo votaron 53\% de los electores. Por AMLO votaron 32 millones, pero en México hay, cuando menos, 54 millones de pobres y 6 millones en extrema pobreza. En primera instancia, 28 millones de pobres no votaron, sin considerar a quienes sí votaron, pero lo hicieron por otros partidos. 
de consenso político entre las élites en torno a la continuidad del modelo económico-político, ante el eventual triunfo de AMLO y la formación de un cogobierno «izquierda-derecha», y c) la acumulación de indignaciones expresadas en un voto masivo (Márquez, 2018a).

No obstante, es sintomático que AMLO emerge de la nueva izquierda -muy semejante a la nueva derecha — de corte pragmática, «moderna», proempresarial y populista. Es una izquierda residual, no disruptiva del orden social. En el espectro ideológico ya no hay una diferencia sustancial entre izquierdas y derechas, las posturas se confunden; plantean cosas semejantes, con pequeñas diferencias entorno a la distribución del ingreso (énfasis de la izquierda) y seguridad (énfasis de derecha). La democracia liberal al uso se funda en un sistema electoral que no ofrece opciones reales, sin cabida para la izquierda radical, que queda marginada y arrinconada, sino dos o tres candidaturas articuladas, a su pesar, por el mismo proyecto capitalista, que puede adjetivarse como «neoliberal», aun cuando discursivamente expresen matices, discrepancias y variantes discursivas, hasta simular su opuesto, lo «posneoliberal». Es parte del «juego democrático» liberal, reducido a las elecciones y la distribución del poder entre los personeros de la llamada «clase política».

La izquierda posibilista y pragmática opera con los ojos puestos en la siguiente elección, mientras tanto realiza actos de gobierno donde «se hace lo que se puede», no lo que se necesita, de acuerdo al estado de ánimo del gran líder y de sus allegados, quienes suponen representar el ser nacional. La izquierda posibilista pacta y cogobierna con la derecha pragmática, cuyo punto de confluencia es el consenso neoliberal, que recupera la noción de Estado mínimo, la modernización tecnológica y la pérdida de sentido en la diferencia izquierda-derecha. Mantiene un discurso «cercano a 
la gente», vende la ilusión del cambio, pero utiliza métodos pragmáticos. Es consecuente con la noción de democracia como mera alternancia electoral, donde tengan cabida en los puestos del gobierno y el parlamento. Ha renunciado a cualquier utopía, al cambio social: no hay condiciones ahora, quizás después. Por lo pronto, es administradora de los intereses del gran capital, que ideológicamente es de derechas, con un esquema redistributivo que reedita el viejo paternalismo priista.

La retórica del cambio alimenta la esperanza de las bases sociales de apoyo, pero mantiene a buen resguardo la esencia conservadora de una sociedad que se mueve entre la tradición, la religión y el apego a un líder fuerte, carismático, paternalista.

El hecho de disponer de mayorías parlamentarias exige a Morena y a sus aliados argumentar a favor de las propuestas, más allá del beneplácito del presidente, dentro de un proyecto de transformación, que por lo pronto brilla por su ausencia.

\section{Social-transformismo}

¿Cuál es el sentido de la transformación social propuesto por AMLO y Morena? La gran apuesta del proyecto se denomina «cuarta transformación» (4T), en referencia al curso de la historia patria: independencia, revolución y reforma. Es el relato oficial que comenzó a escribirse en el siglo XIX, por encargo del gobierno liberal, y que se ha plasmado en la historia de bronce que se ha enseñado en la educación primaria, plagada de héroes, hazañas y símbolos plasmados en efemérides, actos cívicos conmemorativos y demagogia gubernamental. Ha fungido como la ideología del Estado mexicano vertebrada por el nacionalismo revolucionario de cuño priista. En 
esa invocación se omiten los hechos precedentes, desde la Conquista, y omite también la historia más reciente, la gran transformación neoliberal, que sigue vigente, es decir, se dan grandes saltos en el devenir histórico y, por si fuera poco, se asume, prematuramente, que estaría en curso la cuarta transformación, cuyo nombre, definición y contenido no es del todo claro. Para algunos es antineoliberal o posneoliberal, para otros es liberal y neoliberal, para otros es simplemente una ocurrencia. Pero cuando menos es un eslogan efectivo para la propaganda gubernamental.

Más allá de la retórica oficial, la disyuntiva que se abre es si el proyecto de gobierno de AMLO representa un proyecto de cambio de sistema o un cambio que en realidad da continuidad a su funcionamiento, depurándolo de algunos actos de corrupción selectivos, para disminuir a los opositores. El desafío consiste en desbrozar el doble enigma sobre a) un cambio de régimen político o una peculiar forma de gobierno que seguirá reproduciendo el sistema de poder oligárquico, y b) un cambio de proyecto de desarrollo (neoliberal) o continuidad de formas de gobierno y gestiones que prolongan las dinámicas del capitalismo mexicano subsumido al gran capital global. Sea como fuere, estos factores y la emergencia del nuevo gobierno no constituyen de por sí una gran trasformación, una cuarta, según el discurso oficial. Apenas es el anuncio de un gobierno en formación que se enfrenta a un cúmulo de contradicciones y ambigüedades, problemas y contrasentidos, que sólo el devenir de los hechos, con el paso del tiempo, y según los resultados, podrá o no dictaminarse si se ha consumado la susodicha «cuarta transformación».

Por lo pronto, se requiere desmontar los dispositivos ideológicos y propagandísticos que predominan en el discurso oficial y detectar su cometido político, sus compromisos con los intereses concretos de la sociedad 
civil, las clases sociales y los poderes fácticos. Las diversas expresiones políticas pueden tomar las siguientes expresiones:

El proyecto neoliberal: en esencia, el neoliberalismo no es la corrupción sino la embestida del poder y el capital contra los trabajadores, organizaciones sociales e instituciones que las protegen. Los neoliberales reclaman una menor presencia del Estado (menos impuestos, menos regulación), pero requieren un Estado fuerte para desplegar el proceso de acumulación, ampliar los mercados y garantizar la seguridad y el orden. No sólo se antepone la ley privada a la ley pública, sino que se amplía el margen de apropiación del excedente por el capital a expensas de los asalariados.

El proyecto reformista: de inspiración socialdemócrata y de ascendencia keynesiana, el reformismo siempre busca restañar a los problemas del capitalismo mediante la intervención estatal y el rencauzamiento de la acumulación y la rentabilidad capitalista, con concesiones a los trabajadores. Su presencia es más solícita cuando el ciclo económico se precipita en la forma de crisis y se requiere recomponer el rumbo. Esta tónica ha sido afín al desarrollismo latinoamericano, la expansión del capital industrial y comercial, y adquiere matices multicolores con formulaciones como el capitalismo con rostro humano y el resurgimiento del estatismo.

El proyecto de la izquierda posibilista. El proyecto electoral de la izquierda posibilista navega entre la indefinición ideológica y el pragmatismo político. Significa la bancarrota ideológica de la izquierda, que renuncia al cambio de las estructuras sociales y las relaciones de producción, para entregarse a las formas de cogobierno con la derecha, al compartir su programa económico político y promover pequeñas modificaciones en el corto plazo, mejoras asistencialistas entre los pobres, que son su clientela electoral y proyecto como el «progresismo», el populismo, el 
«posmodernismo», las luchas identitarias, la micropolítica y la disputa por los puestos parlamentarios y gubernamentales. Son expertos gestores de la crisis y se asumen como equilibristas en la correlación de fuerzas para estabilizar al Estado en crisis y encauzar la acumulación de capital.

El proyecto revolucionario: el punto de referencia no es el neoliberalismo de por sí, sino el capitalismo como modo de producción y sistema de poder, al cual se pretende transformar de raíz para convertirlo en una nueva sociedad, que difusamente puede advertirse como poscapitalismo, pero que de manera más certera aluda al socialismo y al comunismo, no sin hacer la crítica de los proyectos habidos en su nombre.

La izquierda dominante en México, como en muchos países en el mundo, es de corte reformista y posibilista, incluso conservadora, pero claramente no tiene un solo matiz de reformismo radical, pues no busca cambiar el sistema económico-político, sino que sólo pretende paliar sus efectos más nocivos. Para ello plantean un «Estado social», un «Estado benefactor», un «Estado desarrollista» o un «Estado progresista», que reavive el proceso de crecimiento económico con el capital privado e implemente programas sociales, con aumento del gasto en servicios públicos, para lo cual se precisa más inversión privada y mayor recaudación impositiva.

\section{Del «proyecto alternativo de nación» al Pejenomics}

A nivel discursivo, la némesis de la $4 \mathrm{~T}$ es el neoliberalismo, pero se le reduce a un problema de corrupción de los políticos, específicamente a los que son opositores al gobierno; en tanto que los adeptos al régimen de raigambre neoliberal no pasan por ese tamiz. Esta caracterización es reduccionista y, por tanto, simplista. Atribuye al neoliberalismo la capacidad de 
sobredeterminar la realidad del pasado y del presente. Pero el neoliberalismo no se reduce a un programa económico o ideológico ni a la identidad de gobiernos coaligados de derecha ni a la proliferación de la corrupción y la inmoralidad. Como proyecto político de las clases dominantes, tiene una connotación más profunda, que representa una gran fractura histórica en la disputa por la apropiación de la riqueza social, que se expresa en una brecha notable trazada por el incremento de la productividad y el decremento salarial. En definitiva, significa la supremacía del capital sobre el mundo del trabajo. Asumir que el problema principal es la corrupción es un encubrimiento de la realidad.

En el discurso político oficial se decreta el «fin del modelo neoliberal y su política económica», y proclaman intenciones que no se llevan a la práctica:

Estamos iniciando una etapa nueva, es un cambio profundo, una transformación; no es un simple cambio de gobierno, es un cambio de régimen. Es el momento de expresar que para nosotros ya se terminó con esa pesadilla. Declaramos formalmente desde Palacio Nacional el fin de la política neoliberal, aparejada esa política con su política económica. Quedan abolidas las dos cosas: el modelo neoliberal y su política económica de pillaje, antipopular y entreguista (López, 17 de marzo de 2019).

Frente al neoliberalismo, no se fija una postura conceptual y política clara, más allá de una abrogación por decreto del llamado neoliberalismo y expresiones vagas sobre el posneoliberalismo y el combate a la corrupción como premisa y la austeridad como norma de gobierno. En términos categoriales, el proyecto de desarrollo de la $4 \mathrm{~T}$ puede definirse como una 
expresión tardía del neodesarrollismo, que se basa en la gestión estatal del desarrollo con el papel protagónico de la burguesía nacional más una política asistencialista para los sectores más empobrecidos, es decir, es una formulación que engloba estatalismo, con neoliberalismo y populismo (Bresser, 2010, Katz, 2015; Márquez, 2018a).

Sin embargo, en el peculiar proyecto «neodesarrollista» del lopezobradorismo no hay un concepto orientador progresista semejante a los que promulgó la vertiente latinoamericanista que invocaba términos como «vivir bien» (Bolivia), «socialismo del siglo XXI» (Venezuela) o «revolución ciudadana» (Ecuador). Cuando menos, en las candidaturas previas había expuesto el término paraguas de «proyecto alternativo de nación» y en la última contienda ganadora, se apresuró a dar un viraje proempresarial con el programa denominado Pejenomics: hacia una economía para todos, ${ }^{2}$ un prontuario de políticas y programas de fomento preferente a la inversión empresarial privada alineada con las sacrosantas señales de la macroeconomía.

El proyecto de desarrollo centrado en la inversión privada, el Pejenomics, formulado e implementado por su jefe de gabinete, el empresario de derechas Alfonso Romo, no plantea configurar una nueva organización de la economía, sino navegar sobre las olas del modelo existente: «Economía de libre mercado con la prédica de primero los pobres», es decir, se asume como desarrollista (crecimiento, libertad empresarial libre comercio, zonas especiales, megaproyectos) con política asistencial (adultos mayores y jóvenes).

2 Pejenomics: hacia una economía para todos, vol. 1, en https://drive.google.com/file/ d/1GQgu7iT-fGn-HTFNJY9WyAXgeBuAu0jo/view; vol. 2, en https://drive.google.com/file/ d/IMAgcGSemslKGiYR90SF_AIdaCVzJhkX-/view 
Un ingrediente insertado en la visión de desarrollo es la del nacionalismo, herencia del pasado priista, el nacionalismo revolucionario. La vena nacionalista del lopezobradorismo es una añoranza del «desarrollo estabilizador», el «milagro mexicano», anclado en el contexto internacional de crecimiento denominado los «años dorados» del capitalismo de posguerra (1945-1973), e incubado por el priismo de los presidentes Adolfo López Mateos y Gustavo Díaz Ordaz, donde se consiguieron tasas de crecimiento de 4\% anual entre 1954-1970. Con esa añoranza y la guía del libro Desarrollo estabilizador del entonces secretario de Hacienda, Antonio Ortiz Mena (1998), AMLO pretende elevar la tasa de crecimiento económico de $2 \%$, cuando asumió el cargo, a 4\%, y de 6\% al final del sexenio, en ello cifra su meta económica. La fórmula del desarrollo económico, cual si fuera una segunda vuelta del desarrollo estabilizador, es crecimiento + distribución del ingreso.

En el curso de la historia del capitalismo moderno en México, desde la posguerra, cuando a nivel mundial se imprime un nuevo impulso a la espiral de acumulación mundial, se verifica el tránsito de dos grandes modelos de desarrollo: el «desarrollo estabilizador», una segunda etapa de la industrialización por sustitución de importaciones que vivió periodos de crecimiento y la vigencia del pacto populista (revolución pasiva) hasta su agotamiento (la «docena trágica» referida a los gobiernos de Luis Echeverría y López Portillo), y el «neoliberalismo» desde Miguel de la Madrid a la fecha, y actualmente estamos en el impasse de la 4T. El proyecto de la $4 \mathrm{~T}$ es deliberadamente ambiguo y contradictorio, difuso y pragmático, voluntarista y moralista, que navega a la deriva en un mundo inmerso en una profunda crisis civilizatoria. Dice ser «posneoliberal», pero arrastra los fundamentos del neoliberalismo que dice denostar combinados con 
prácticas populista. Pareciera ser un oxímoron, pero una definición preliminar de este proyecto pudiera ser un neoliberalismo populista. Su vena neoliberal se detecta en la persistencia de la ortodoxia macroeconómica, la subordinación al capital global (TLCAN-T-MEC), la reticencia a la fiscalidad progresiva, la férrea austeridad, los ajustes y recortes, etcétera; en tanto que el populismo se apuntala con las transferencias monetarias focalizadas, el discurso demagógico y la procreación de una base social de apoyo electoral.

En el renglón político-ideológico, la noción de «cuarta transformación» más bien pretende establecer una línea de continuidad con el nacionalismo de la historia patria, una forma de nacionalismo burgués de talante decimonónico, cuya última gran transformación fue el proyecto neoliberal, precisamente el derrocamiento desde el Estado del proyecto nacionalista, que habría quedado obsoleto frente al impulso de la globalización capitalista. Adicionalmente, se alinea con una noción mínima del progresismo latinoamericano: crecimiento económico + distribución social del ingreso, dentro de los márgenes del capitalismo subdesarrollado y dependiente, mediante el estímulo a la inversión privada y pública de carácter rentistas, con énfasis en el sector petrolero, y la formación de una bolsa fiscal para financiar programas de asistencia social, donde se procrean las bases de apoyo electoral que sustentan la continuidad del proyecto de gobierno; pero sin crear bases para una reconversión productiva que aliente el crecimiento ni soportes fiscales para la distribución, mucho menos para transformar las estructuras económicas y sociales en pos de una transición hacia un sistema poscapitalista.

Pero sus intenciones son más pragmáticas, alineadas con la economía de mercado a cargo de los grandes capitales. Ante el diagnóstico de falta 
de crecimiento y como contraposición el periodo neoliberal de estancamiento crónico, se pretende impulsar un nuevo ciclo de crecimiento económico con políticas convencionales, como la promoción de los megaproyectos y los polos de desarrollo en zonas preferentes, modalidades que antes se criticaban por ser depredadoras de la naturaleza, expoliadoras de los pueblos y concentradoras de la riqueza, ahora súbitamente se presentan como fuentes de la bonanza y la prosperidad.

La expectativa de reformas y mejoras del proyecto de regeneración nacional pasa por alto el hecho de que el viejo régimen, por más corrompido y decadente que sea, está sostenido por la fuerza del poder de las clases dominantes, el imperio y la oligarquía, que pervivirán en la estructura de poder y serán influyentes en los gobiernos que pretenden implementar una transición pactada.

En 1970, Luis Echeverría era presentado como el mesías de «el «cuarto movimiento〉 de nuestra sinfonía histórica», como parte de una revolución inconclusa, que tenía como referente inmediato el nacionalismo revolucionario, la constitución de 1917. Asimismo, se advertía que la disyuntiva era «Echeverría o el fascismo» (como exclamaron intelectuales de izquierda como Fernando Benítez y Carlos Fuentes, entre otros), para confrontar al movimiento estudiantil y las organizaciones obreras, campesinas y populares de izquierdas y para contener el ascenso de la derecha oligárquica, por lo que Echeverría era lo menos malo. Guardadas las distancias y contextos, el proyecto de AMLO retoma la noción de cuarto movimiento o cuarta transformación en el curso de la historia patria que ha pergeñado la ideología del nacionalismo revolucionario de cuño priista, a la vez que su discursividad presidencialista estira la cuerda y tensa las posiciones al punto de expresar que no hay medias tintas o se está con su proyecto o se 
está en contra. Este discurso maniqueo reduce las posiciones políticas en dos frentes, de talante decimonónico: liberales vs. conservadores. Habría que advertir, sin embargo, como lo hiciera Marx (2003:31): «Hegel observa en alguna parte que todos los grandes hechos y personajes de la historia universal acontecen, por así decirlo, dos veces. Olvidó añadir que, una vez, como [gran] tragedia, y la otra, como [lamentable] farsa». Con esta sentencia criticaba a los movimientos políticos que bajo ropajes de héroes y eventos del pasado enarbolan luchas y consignas anacrónicas con las que sólo ocultaban su demagogia.

\section{Paradoja neoliberal}

El modelo económico neoliberal ha sido sintetizado por John Williamson en el decálogo del «Consenso de Washington», donde la inversión extranjera y la privatización, puntales ambos de los proyectos estratégicos de la 4T, son determinantes. Al respecto, Williamson expresaba que «estas inversiones pueden aportar el capital necesario, habilidades y know-how (...). La principal motivación para restringir la inversión extranjera directa es nacionalismo económico, que Washington desaprueba» (Williamson, 1990). A su vez, la privatización era otra de las políticas principales:

La privatización puede ayudar a aliviar la presión sobre el presupuesto gubernamental, tanto en el corto plazo por los ingresos producidos por la venta de la empresa y en el largo plazo en la medida en que la inversión no necesita ser financiadas por el gobierno. Sin embargo, la principal justificación para la privatización es la creencia de que la industria privada se gestiona de manera más eficiente que las empresas estatales (Williamson, 1990). 
Por tanto, «esta creencia en la superior eficiencia del sector privado ha sido durante mucho tiempo un elemento de fe en Washington» (Williamson, 1990).

La paradoja neoliberal de la «cuarta transformación» consiste en que dice ser un proyecto antineoliberal cuando las políticas centrales del modelo neoliberal — como la inversión privada, la inversión extranjera y la privatización - persisten, y son puntales, en el programa de gobierno que dice abrogar, por decreto, el neoliberalismo, y todos los días se encarga de abjurarlo, pero la realidad dice otra cosa muy distinta. De hecho, se brindan todas las concesiones a los grandes empresarios que hacen pactos políticos con el gobierno, p. ej. medios de comunicación, la inversión público-privada en grandes obras de infraestructura. Aun cuando es una quimera suponer que existe un empresariado «nacionalista», menos aún que vele por el interés común de la nación abstracta, sino que obra en función de sus intereses personales y los de su clase, la capitalista, impelida por la obtención de ganancias y el enriquecimiento. Inclusive, se podría caracterizar a la burguesía nacional como «lumpenburguesía» (Frank, 1972), dado que se trata de un empresariado rentista que vive a la sombra del Estado, favorecida por los contratos, concesiones, subsidios, exenciones y otras canonjías y privilegios. Navegan entre los sucesivos gobiernos de la alternancia sin compromisos político-ideológicos, a no ser los de sus propios negocios expansivos

La política de crecimiento está vinculada con un inevitable alto costo social y ambiental debido a los megaproyectos pasados, presentes y futuros, que concitan el despojo, la proletarización, el extractivismo y la depredación ambiental. La política de distribución del ingreso mediante la estrategia de focalización en sectores pobres (transferencias monetarias o 
subsidios a grupos específicos) o políticas universales de distribución del ingreso (p. ej., salario indirecto, canasta básica alimentaria, subsidios a bienes salario) son variantes de la «nueva política social» del neoliberalismo, ${ }^{3}$ que dispone de una política asistencialista para mantener un soporte social mínimo sin transformar la trama de las relaciones sociales: desde un horizonte conceptual del liberalismo social antes se hablaba de «desarrollo social», y ahora se alude tibiamente a «bienestar».

Así como el neoliberalismo, en tanto proyecto de clase, fue exitoso para modificar la correlación política de fuerzas a favor del gran capital y orientar las funciones estatales a sus intereses, permitiendo la concentración de capital y riqueza, así también el Tratado de Libre Comercio de América del Norte (TLCAN), y su versión actualizada de Tratado entre México, Estados Unidos y Canadá (T-MEC), debe entenderse como un proyecto de integración regional de los capitales multinacionales y nacionales que comandan la economía mexicana y de la zona, y que sus resultados no se miden por el crecimiento limitado del país ni la devastación social sino por la acumulación progresiva de capital a escala regional. Ambos proyectos siguen vigentes, aunque cambien de nombre e independientemente de la alternancia electoral.

Aún está por definirse si la autodenominada «cuarta transformación», en realidad es una variante de la gran transformación neoliberal en su sexto ciclo sexenal, que quisiera imprimirle como sello distintivo un nuevo

\footnotetext{
${ }^{3}$ La nueva política social del neoliberalismo se implementa en América Latina desde la década de los setenta del siglo pasado, en los países pioneros del neoliberalismo, como Chile y Bolivia, pero va refinándose conforme se adopta la «transición a la democracia» dentro del propio neoliberalismo y la necesidad de generar una base social de apoyo. Las políticas asistencialistas y clientelares, soportadas por la perspectiva del liberalismo social, tendrán un gran desdoblamiento en el funcionamiento de ese modelo de desarrollo.
} 
rostro humano al capitalismo neoliberal desde una perspectiva moralizante y austera.

\section{Gestión estatal posneoliberalizada o la ortodoxia rediviva}

El Estado asume parcialmente la gestión del desarrollo. Funciones estatales asumidas por el Estado durante el modelo neoliberal han sido ratificadas y profundizadas, tanto para la expansión del capital, como para la apertura de nuevos espacios de valorización, al igual que para reinsertar a sectores pauperizados a la órbita del consumo. Sin embargo, es una gestión incompleta y ambigua, que garantiza espacios al gran capital multinacional y nacional, en sectores rentables vinculados a la exportación y al mercado interno de alto consumo, pero deja inconclusos sectores estratégicos para el desarrollo: bienes de capital, alimentario, educativo, científico-tecnológico... Confiere un activismo al Estado en la promoción de la expansión del capital mediante, por ejemplo, la creación de zonas económicas especiales (ZEE) o el pago de la nómina de grandes empresas privadas. No es muestra de la vigencia del precepto liberal laissez faire, laissez passer (dejar hacer, dejar pasar), si no de un capitalismo donde el Estado funge el gerente del capital, como capitalista colectivo, bajo la fórmula de «gastos públicos, ganancias privadas». A la postre, es un modelo híbrido de gestión entre una economía de libre mercado y un capitalismo monopolista de Estado, en todo caso una economía mixta inconclusa.

Al igual que la tecnocracia neoliberal, las «señales del mercado» se siguen tomando como el criterio toral para la toma de decisiones. Garantizar las condiciones macroeconómicas para las ganancias y continuar con la tributación al capital financiero internacional. AMLO no va a revocar 
concesiones y contratos, salvo algunos de efecto mediático, tampoco se advierte una reforma sustancial a la hacienda pública con la intención de subir impuestos en escala progresiva ni de cambiar la constitución para afincar una plataforma política de transformación social, salvo enmiendas de ocasión. De lo que se trata es de brindar certidumbre a los participantes en el mercado, los grandes capitales monopolistas internacionales y nacionales, con la coparticipación del Estado en proyectos de infraestructura y energéticos, en una ruta inercial con el continuismo capitalista. Decididamente, el esquema de gobernación es un cogobierno entre facciones de la izquierda nacionalista y la derecha empresarial, que se orientan por un proyecto de república de corte nacionalista burgués.

A contrapelo de la historia, el presidente está obstinado en restituir el rentismo energético del petróleo y la electricidad. Para revivir viejas glorias de Petróleos Mexicanos (Pemex) y la Comisión Federal de Electricidad (CFE), empresas públicas que producirían energía y arrojarán una renta energética, con la cual financiar las arcas públicas y redistribuir el ingreso mediante programas de asistencia social. Esta es la vía más expedita de la fórmula del desarrollo que se proclama desde la década de los sesenta, con el «giro social» del Banco Mundial, ante el fracaso de las políticas de modernización $=$ crecimiento económico + distribución del ingreso, misma fórmula que ha sido retomada por el progresismo neoextractivista, que incentiva los megaproyectos para captar una parte de la renta y financiar al Estado y sus programas sociales. El inconveniente es que Pemex fue prácticamente desmantelada y los sectores estratégicos concesionados al capital privado, nacional y extranjero, al igual que la generación de electricidad. Pemex tiene una colosal deuda y requiere mucho dinero para restaurarla. Pero el mercado mundial de hidrocarburos está en descenso, no 
sólo porque está en curso la transición energética, sino porque los precios internacionales son inestables, con caídas precipitadas a la baja, haciendo incosteable en el mediano y largo plazo a esta industria. Los gobiernos de las economías desarrolladas adoptan medidas para transitar hacia las energías «limpias» (eoloeléctrica, solar) y dejar atrás las energías sucias (hidrocarburos, carbón, combustóleo, diésel). Las industrias se preparan para tomar como fuente primaria de energía a la electricidad y no a la gasolina. ¿Qué es más redituable: importar gasolinas baratas o producirlas con un altos costo de producción y un sacrificio a las finanzas públicas?

\section{Entre el capital y el trabajo}

\section{Por el bien de todos... primero ¿los pobres, los ricos o los gobernantes?}

La disputa por la cuestión social está invisibilizada en el debate nacional, pero es la más crucial. ${ }^{4}$ Los oligarcas, que se sienten dueños del país, abogan por una macroeconomía acorde a las señales del mercado (inflación estable) y la contención a rajatabla de los costos laborales en contra de los intereses de la mayoría de los trabajadores que perciben salarios ínfimos y luchan, esporádicamente, de manera desarticulada, por preservar

\footnotetext{
${ }^{4}$ Los organismos y organizaciones internacionales reconocen que México es el país más desigual de América Latina (Vázquez, Delgado y Jaramillo, 2018). Incluso las propias instancias promotoras, como la Organización para la Cooperación y el Desarrollo Económicos (OCDE, 2018), desde una visión estática, advierten que un hipotético mexicano pobre requeriría 150 años para volverse rico, en caso de que pudiera vivir esos años y de que se activara la escalera de «movilidad social»; en ese tenor, «México parece tener relativamente menos disponibilidad que otros países de América Latina o economías emergentes».
} 
prestaciones, salarios y empleo. En ese contexto, es paradójico que AMLO, y su autodenominada «esperanza de México», predique que en el país, como si fuera una excepción mundial, no hay explotación, porque los oligarcas, los magnates afines a su administración, son generadores de riqueza y empleo con riquezas «bien habidas», y su gobierno se integra por facciones de la burguesía nacional, en tanto que sus programas estrella se orientan a respaldar los planes de negocio: megaproyecto, subsidio a nóminas, TLCAN, etcétera. No en balde expresa sin tapujos el mantra neoliberal: «El mercado se regula con el marcado» (Forbes, 12 de marzo de 2020). En la misma tesitura, pide al Banco de México no intervenir en el mercado para «fortalecer al peso» (Redacción, 12 de marzo de 2020).

Por la vía del continuismo, AMLO descartó que las «reglas del juego» del neoliberalismo fueran a cambiar: «No va a haber reformas promovidas por el Ejecutivo que afecte a la banca de México y la banca que trabaja en nuestro país, vamos a mantener el mismo marco legal» y que «si hay algún cambio saldrá de ustedes y pensando siempre en la competencia. Los bancos se regulan con los bancos, el mercado se regula con el mercado» (Redacción, 13 de marzo de 2020).

El proyecto de desarrollo nacional de AMLO va a sostener la reproducción del capital con particular énfasis en los intereses del capital sobre los del trabajo. Se trata de un proceso fáustico que pretende «hacer historia», pero al fin de cuentas es un proceso de modernización capitalista plagado de contradicciones. Un proyecto de cambio, cuando menos, debería afectar intereses creados del gran capital, pero AMLO se ha mostrado condescendiente con ellos y afecto a sus intereses, salvo con las facciones del capital que manifiestan una abierta oposición política a su proyecto, es decir, los empresarios panistas y priistas. 
El jefe de la oficina de la presidencia, Alfonso Romo, vínculo político de la $4 \mathrm{~T}$ con el capital privado, ha expresado que pretenden convertir a México en «un paraíso de la inversión». Para tal efecto, han creado el Consejo Nacional para el Fomento a la Inversión, el Empleo y el Crecimiento Económico, que tiene el cometido de «promover la inversión, fomentar el desarrollo económico y fortalecer las fuentes de empleo en el país» (Segob, 17 de mayo de 2019). ${ }^{5}$ Por supuesto, no existe parangón con las organizaciones de trabajadores, movimientos sociales y organizaciones ciudadanas, a quienes se ve con recelo y habitualmente se engloba, en una visión maniquea, como sectores «privilegiados», «corruptos» $\mathrm{y}$ «conservadores», salvo que se subsuman a las politicas de recortes indiscriminados y respalden políticamente sus proyectos. Lo mismo puede decirse de los empresarios que no son cercanos, políticamente, a AMLO, que no han pasado por el tamiz purificador y se quedan en la órbita política de los «conservadores». El simplismo es tal que hay empresarios «conservadores» $\mathrm{y}$ "progresistas», según estén a favor o en contra del líder político en cuestión.

En México el capital está altamente concentrado, con una mezcla de empresas privadas y públicas, nacionales y multinacionales. Hay 5.6 millones de establecimientos, pero sólo $0.2 \%$ concentra $64 \%$ del producto interno bruto (PIB) (mil empresas grandes concentran 56\% del PIB y 28.8\% del personal ocupado), y 246 mil pequeñas y medianas empresas (Pymes)

${ }^{5}$ El Consejo empresarial está conformado por conspicuos personajes de la otrora «mafia del poder» (López, 2007), la némesis del lopezobradorismo, que se reconvirtió por efecto de una transubstanciación al estilo de la 4T en el exclusivo Consejo Asesor Empresarial: Bernardo Gómez (Televisa), Olegario Vázquez (Grupo Empresarial Ángeles), Carlos Hank (Banorte, Gruma y Hermes), Daniel Chávez (Vidanta), Miguel Alemán (Interjet) y Ricardo Salinas (TVAzteca, Elektra, Banco Azteca). Asimismo, es omnipresente la figura de Carlos Slim (Grupo Carso). 
aportan 25.1\% del PIB y 31.4\% del personal ocupado. Las grandes empresas que operan en México, tan sólo mil de ellas, generan 65.2\% de PIB, concentran 62\% de los activos fijos, pagan 40\% de las remuneraciones totales y dan empleo a 16\% del personal ocupado en el país. Entre las principales empresas de México se encuentra Petróleos Mexicanos (Pemex), América Móvil, Wal-Mart, Comisión Federal de Electricidad (CFE), Fomento Económico Mexicano (FEMSA), General Motors, Alfa, Fiat Chrysler (FCA), Bimbo, Cemex, Bimbo, BBVA-Bancomer, Volkswagen, Grupo México (Expansión, 2019). Asimismo, México encabeza la lista de empresas traslatinas, multinacionales de la región, o empresas mexicanas globales: Pemex, América Móvil, FEMSA, Alfa, Bimbo, Cemex, Grupo México, entre otras.

Para la 4T los empresarios lo son todo: son los agentes inversionistas, generadores de crecimiento, creadores de empleo y promotores del bienestar. Los principales proyectos de la $4 \mathrm{~T}$ tienen como protagonista central al gran capital privado y el gobierno es garante y coinversionista. Los pobres son sujetos pasivos beneficiarios de programas de asistencia y los trabajadores son un sector desdibujado, que no está en el radar del gobierno como sujeto colectivo protagónico de la transformación, si acaso como masa electoral que es convocada ritualmente a los comicios bajo la investidura de la entelequia llamada «pueblo».

\section{Desvalorización del trabajo}

México es un país de trabajadores que generan la riqueza y soportan todo el modelo económico-político en el país orientado a la exportación bajo cadenas de valor global, pero que también hacia el mercado nacional, además de que es el principal proveedor de trabajadores para la economía 
estadounidense vía la migración laboral. Pero la denominación misma de trabajador se encubre bajo términos como «emprendedores», «empresarios independientes» $\mathrm{o}$ «empleados», «colaboradores» $\mathrm{O}$ «asociados» dentro de las empresas. En esa tónica, la figura del trabajador no es reivindicada por el lopezobradorismo, a lo sumo la figura abstracta de «pueblo» o «pobres», sin referencia a las relaciones de producción.

La población trabajadora es mayoritaria. De acuerdo a las estadísticas oficiales, para 2019, en México había 55.6 millones de población ocupada, de la cual $68.2 \%$ eran asalariados, $22.5 \%$ trabajan por cuenta y $4.5 \%$ son trabajadores no remunerados, en tanto que sólo 4.8\% son propietarios que ocupan trabajadores (INEGI, 2020).

No obstante, la mayoría de los trabajadores no se expresa en un poder político ni en mejores condiciones de trabajo. México es el país de la OCDE que más horas se trabaja (2 mil 255 horas al año en promedio: 43 horas a la semana) (OCDE, 2020), también es el país con menos días de vacaciones, $70 \%$ de los mexicanos no tendrá pensiones, $60 \%$ trabaja en la informalidad. ${ }^{6}$

Fiel reflejo de la política neoliberal, cuyo eje central es la desvalorización del trabajo, el ingreso salarial en México lleva más de tres décadas y media desplomándose, desde el punto de vista de su poder adquisitivo. Hay muy pocos países en que la participación salarial haya caído tanto como en México, incluso en el contexto de América Latina, donde el salario crece y en México permanece estancado. Desde 2019 se precipitó la participación del salario en el PIB nacional. Asimismo, hay una recomposición del empleo hacia la baja remuneración: crecen los empleos precarios y decrecen

\footnotetext{
${ }^{6}$ En Japón existe un fenómeno denominado karoshi, que significa «morir por demasiado trabajo», aunque se trabaja en promedio menos horas que en México (mil 713 horas, 542 horas menos que México).
} 
los empleos estables. También hay un deterioro acusado en las remuneraciones de los trabajadores con mayor nivel educativo (media superior o superior), un movimiento a la baja que tiende a acercarlos a los trabajadores con bajos niveles de instrucción (de secundaria hacia abajo). Sólo 37\% de los ocupados percibe más de tres salarios mínimos y apenas 5.2\% percibe más de 5 salarios mínimos, el umbral de ingresos que se considera adecuado para acceder a una canasta básica acorde a la vida contemporánea. Casi 40\% de la población no cubre la canasta alimentaria o, dicho de otro modo, está en situación de infrasubsistencia. Esta circunstancia no se puede atribuir a la productividad, pues si el nivel del salario mínimo hubiera crecido junto con el crecimiento de la productividad ya habría superado la línea alimentaria, es decir, la subsistencia básica. El salario mínimo está por debajo del umbral de subsistencia, está desvalorizado estructuralmente.

Para 2017, la brecha entre ganancias del capital y remuneraciones a los trabajadores es la más amplia que se ha registrado en México: en términos del ingreso nacional, $74 \%$ se va para el capital como rentas, dividendos e intereses, y 26\% restante a los trabajadores, como salarios. Es la desigualdad más amplia desde los 70 (González, 21 de octubre de 2019).

Según la Comisión Nacional del Sistema de Ahorro para el Retiro (Consar), 70\% de la población económicamente activa mexicana no cuenta con pensión contributiva (en Chile y Costa Rica es de 34\% y en Uruguay de 28\%, el promedio en América Latina es de 60\%), los recursos aportados por el trabajador (1.1\% del salario base), el patrón (3.1\% del salario) y el Estado (0.2\%), durante la vida laboral del trabajador en las cuentas individuales manejadas por la Administradora de Fondos de Ahorro para el Retiro (Afores). En México, 57\% de la población ocupada trabaja en la informalidad y no cotiza en un sistema de pensiones. Muchos trabajadores 
no forman parte de la seguridad social o tienen trayectorias muy intermitentes entre la formalidad y la informalidad, por lo que no podrán acceder al sistema de pensiones en su retiro.

El trabajo precario y el llamado trabajo independiente diluye la posibilidad de que tendrá acceso al sistema de pensiones en su retiro, pues no cuenta con empleo formal. El esquema de Afores requiere haber cotizado aproximadamente 24 años al IMSS, y al menos 30\% de los trabajadores podrán cumplir esa meta. El nivel de aportación es de 6.5\% del salario en la cuenta individual del trabajador. Aproximadamente 75\% de los trabajadores cotizan con menos de 5 salarios mínimos, y entonces recibirán la pensión mínima. Amén de que las comisiones que cobra la Afore son altas.

\section{La senda de la superexplotación}

Frente al régimen de superexplotación, es decir, la desvalorización de la fuerza de trabajo, uno de los datos más persistentes en los últimos tiempos, en el lopezobradorismo no hay un pronunciamiento concreto al respecto, salvo continuar con la política asistencialista y electorera de transferencias monetarias o subsidios a familias pobres: subsidio a nóminas de grandes corporaciones, incremento reducido del salario mínimo, reconstrucción de relaciones con el sindicalismo oficialista y democrático, privilegio a los grandes capitales (señales del mercado y México como paraíso de la inversión) y megaproyectos con esquemas de financiamiento público-privado. El discurso es proempresarial, no a nombre de los trabajadores, a quienes se suple con la entelequia del pueblo.

En línea con los gobiernos neoliberales precedentes, el gobierno de AMLO anunció un incremento pírrico al salario mínimo general diario de 
14 pesos (16\%), notoriamente insuficiente para alcanzar una condición de «salario digno», pues se trata de un salario insuficiente siquiera para comer, con él se tendría que trabajar 21 horas diarias para adquirir la canasta alimentaria recomendable, que tiene un costo estimado de 264.84 pesos diarios (CAM, 2018). A su vez, se ha centrado en los salarios máximos del sector público con techo en el ingreso presidencial y los salarios mínimos de los trabajadores, pero el problema está en los salarios medios, los cuales rigen a la mayoría de los trabajadores, que se encuentran subsumidos en la política persistente de contención salarial.

Aun con el aumento al salario mínimo, las cosas no cambian en el escenario de la economía global del trabajo barato: en México se continuará percibiendo los niveles salariales más bajos de América Latina y la OCDE, seguirá ofertando ese elemento de competitividad espuria. Por lo demás, 102.68 pesos diarios resultan notoriamente insuficientes para superar la pobreza de 54.3 millones de mexicanos postrados en esa situación, según datos oficiales.

\section{Enajenación de becarios}

El programa estrella Jóvenes Construyendo el Futuro significa una fórmula proempresarial que al tiempo que subsidia las ganancias empresariales somete a los jóvenes a la servidumbre laboral: otorga becas (salarios) para que los noveles trabajadores («aprendices») bajo la «tutoría» del empleador (quien puede despedirlo libremente) se inserten en la disciplina laboral. Pese a que la capacitación es una obligación de las empresas (art. 153 de la Ley Federal del Trabajo), bajo el disfraz de un apoyo al trabajador, subyace un subsidio directo a las empresas para sufragar las nóminas y amplificar los márgenes de ganancia, y el Estado funge como una suerte 
de subcontratación (outsorcing) encubierto que pagará con impuestos la fuerza de trabajo regalada a las empresas. Aquí la figura central son las organizaciones empresariales, como el Consejo Coordinador Empresarial (CCE), Concamin, Consejo Nacional Agropecuario, Coparmex, y las empresas beneficiarias: Elektra, Oxxo, Lala, Coca-Cola, Cinépolis, Bimbo, Walmart, Nestlé, Femsa, etcétera. Es decir, mayoritariamente se beneficiarán los consabidos capitales monopolistas de la «mafia del poder». Los empleadores se convertirán en «tutores», luego de un año de trabajo los trabajadores recibirán una constancia de las habilidades aprendidas.

El programa Jóvenes Construyendo el Futuro utiliza la figura del «becario» para precarizar, desde el comienzo, a los noveles trabajadores, considerados aprendices dentro de procesos de valorización en curso. Los becarios se irán adiestrando en el ejercicio subordinado y enajenado de su capacidad de trabajo con una mínima retribución, que le resulta al patrón una fuente de trabajo regalado, y en conjunto se violenta el precepto igualitarista de «a igual trabajo, igual salario, iguales derechos», estipulado en la letra del artículo 36 de la Ley Federal del Trabajo.

Este programa no es nuevo, es un planteamiento de la Organización Internacional del Trabajo (OIT) y ya se aplicaba en las anteriores administraciones neoliberales, por el Servicio Estatal del Empleo de la Secretaría del Trabajo y Previsión Social (STyPS). El gobierno de AMLO destinará 100 mil millones de pesos en forma de salario (becas de 3 mil 600 pesos mensuales, equivalente al salario mínimo, durante un año para 2 millones 300 mil jóvenes) cuyo producto del trabajo será recibido gratuitamente por los empresarios, sin ningún compromiso.

Según el gobierno, el incremento salarial significa dar el gran paso de un salario mínimo a un salario digno. Sin embargo, el incremento salarial 
decretado tiene como plataforma de soporte al programa «Jóvenes construyendo el futuro», mediante la transferencia de una bolsa de 43 mil 300 millones de pesos, esto es, el gobierno pagará el salario de los jóvenes trabajadores inscritos en el programa, lo cual representa un subsidio estatal a la nomina empresarial. Al hacer una comparación entre el pago empresarial del incremento salarial y el subsidio gubernamental, se puede advertir que en realidad el Estado mexicano está subsidiando la nómina del sector empresarial privado. Partiendo de la consideración de que en el país suman 8.5 millones de trabajadores quienes perciben hasta un salario mínimo, los cuales serían objeto del beneficio, y de que al año se cubren 270 jornadas de trabajo, en términos normales, la medida considera un aumento de 14 pesos diarios, por lo que el monto anualizado de la masa salarial incrementada será de 32 mil 130 millones de pesos. En contraste, el gobierno transferirá a los empleadores los 43 mil 300 millones, como subsidio a la nómina, lo que representa 11 mil 170 millones más de lo que los empresarios pagarían por el aumento salarial (CAM-UNAM, 2018). La política salarial significa, en el fondo, un subsidio del Estado al capital, que se duplica si se considera que el producto del trabajo genera su propio pago, como la parte variable del capital, y el subsidio gubernamental significa la transferencia absoluta de ese componente a la ganancia empresarial. El trabajo diario será un trabajo enteramente gratuito y los beneficios serán acrecentados para el empleador sin erogar pago ni riesgo alguno. Además, esto constituye un acicate para mantener el régimen de salario mínimo

Esto significa una transferencia directa a las ganancias empresariales privadas con dinero público. Un capítulo más del neoliberalismo rampante. 


\section{Nuevo sindicalismo: libertad sindical, ¿para quién?}

El T-MEC marca la agenda laboral morenista en México. La reforma laboral para la «libertad sindical» fue una exigencia de los congresistas de Estados Unidos para aprobar el T-MEC, que fue procesada de manera exprés por la mayoría parlamentaria mexicana.

No deja de ser sintomático de las intenciones clasistas del proyecto parlamentario que, según el líder de la bancada morenista, Mario Delgado, la reforma laboral implementada liberará a los patrones de la extorsión de los dirigentes sindicales corruptos, ${ }^{7}$ pues en realidad los líderes «charros» y los dirigentes corruptos a quienes extorsionan no es a los empresarios, sino a los trabajadores, para favorecer a la parte patronal.

Para restablecer y alinear el viejo corporativismo estatista, Morena está impulsando un nuevo sindicalismo y una burocracia sindical alineada a su gobierno, para hacer del partido en el gobierno un partido de masas, como lo fuera el viejo PRI. En esa función destaca el senador morenista Napoleón Gómez Urrutia, dirigente del Sindicato Nacional de Trabajadores Mineros, Metalúrgicos, Siderúrgicos y Similares de la República Mexicana (SNTMMSSRM), y cabeza de la nueva central, la Confederación Internacional de Trabajadores (CIT), que aglutinaría a 150 sindicatos, que pretende desplazar al Congreso del Trabajo. ${ }^{8}$ Con ello se busca atraer al

\footnotetext{
${ }^{7}$ «Los principales beneficiados de la aprobación de la reforma laboral en el Congreso de la Unión serán los empresarios, ya que se pondrá fin a las extorsiones de los líderes de sindicatos «charros»», según el líder de los diputados de Morena, Mario Delgado Carrillo (Chávez, 14 de abril de 2019). ${ }^{8}$ Como lo reconoce su propio líder: «Nace la nueva confederación mexicana de trabajadores marchando junto con el gran proyecto de Cuarta Transformación histórica encabezado por el presidente Andrés Manuel López Obrador, en quien avizoramos un gobernante que ha proclamado la democracia a la que aspira, según él lo ha expuesto, como una democracia del pueblo, por el pueblo y con el pueblo».
} 
viejo sindicalismo «charro» priista y articularlo a las bases morenistas. En esa intentona, se está reclutando al ferrocarrilero Víctor Flores; el nuevo morenista de la Confederación Autónoma de Trabajadores y Empleados de México (CATEM), Pedro Haces; ${ }^{9}$ Reyes Soberanis, de la Confederación Obrera Revolucionaria (COR), y Abel Domínguez, de la Confederación de Trabajadores y Campesinos (CTC). A la usanza morenista, la nueva central se propone, simultáneamente, conciliar los intereses de los derechos de los trabajadores con relaciones constructivas con la empresa o institución. ${ }^{10}$

\section{Austeridad: costos sociales bajo la alfombra}

Bajo el signo de la honradez y combate a la corrupción se impone un régimen neoliberal profundo de austeridad, en realidad ajuste estructural, que tiene en los trabajadores del sector público, el eslabón más débil. Esta es una política cara al proyecto neoliberal que se dice derogar. Los recortes thatcherianos se reeditan mediante el despido masivo de trabajadores y la precarización de las relaciones laborales. Por decreto presidencial, se ejecutó un recorte de 75\% en el presupuesto asignado a las oficinas de la administración pública, que ocasionó una oleada de despidos. Sobre los

${ }^{9}$ El expriista Pedro Haces, a la vez que dirige la CATEM, es senador por Morena y obtuvo el registro de un partido político denominado Fuerza Social por México (FSM), en la nueva constelación de partidos satélite del lopezobradorismo, que también incluirá al partido de Elba Esther Gordillo, denominado Redes Sociales Progresistas (RSP) y al partido evangelista, Partido Encuentro Social (PES), pero los dos primeros serán la vertiente del corporativismo sindical plegado al presidencialismo.

${ }^{10}$ Según el líder emergente: «En esta nueva central se propone defender los derechos de los trabajadores, pero sin menoscabo de las relaciones constructivas con las empresas o instituciones con las cuales sus miembros tienen entendimientos contractuales de trabajo, con un espíritu abierto a la productividad general del país y a la conservación y fortalecimiento de las fuentes de empleo» (Gómez, 14 de febrero de 2019). 
trabajadores despedidos no hay un dato exacto, la presidencia no informa al respecto, pero el gobierno de AMLO ha despedido a una gran cantidad de trabajadores del sector público debido a sus recortes presupuestales. Tan sólo en los primeros seis meses de gobierno se despidieron a más de 11 mil trabajadores de 17 secretarías de Estado, Presidencia de la República y Servicio de Administración Tributaria (SAT), la mayoría puestos de confianza, desde chofer hasta director general (Sin Embargo, 1 de julio de 2019). En la jerga de la 4 T no se trata de «despidos» sino de «ajustes», que se justifican diciendo lo que argumentan los neoliberales en esos casos: los trabajadores están colmados de privilegios y derroches que hay que erradicar. Lo cierto es que los despidos son a rajatabla, sin mediar diagnósticos; el imperativo es hacer un trasvase de recursos, sin reforma fiscal de por medio, de unas dependencias hacia los programas estrella del lopezobradorismo.

El gobierno que se dice antineoliberal está profundizando la precarización laboral, y se ensaña con los trabajadores estatales, donde aproximadamente 4 millones de trabajadores en las dependencias públicas, federales y estatales están proclives a ser expropiados de sus derechos laborales por los cambios en las modalidades de contratación en el sector público, una estrategia lesiva por la cual la institución pública puede expropiar las prestaciones, jubilaciones, pago de vacaciones, FOVISSSTE, además de reducir los salarios.

Al imponer por decreto presidencial el régimen de austeridad, se han ejecutado despidos en el sector público, rebaja en los salarios, cambio en las modalidades de contratación para optar por la precarización. La determinación unilateral de disminuir el gasto burocrático en $75 \%$ ha derivado en medidas absurdas, como la exigencia de que los trabajadores lleven sus 
propias computadoras a la oficina o compren el equipo que utilizan a la propia dependencia donde trabajan, además de disminuir el consumo de agua y de electricidad. Esto sucede en la mismísima Secretaría del Trabajo y Previsión Social (STPS) y en otras dependencias federales.

Estas medidas se adoptan bajo la tónica de que todo es por el bien de la nación, una nación dominada por los intereses del capital financiero y la burguesía exportadora, no por los intereses de los trabajadores, que conforman a la mayoría de la población.

Durante el llamado desarrollo estabilizador, en los sesenta y setenta, el Estado mexicano impulsaba la acumulación de capital y entre otras medidas absorbía los costes de las empresas y otorgaba créditos preferenciales mediante la Banca de Desarrollo Nacional Financiera (Nafinsa). Con la quiebra del modelo y la crisis fiscal del Estado, se adoptó el modelo neoliberal, y para las décadas de los ochenta y noventa las inversiones estatales se tornaron insostenibles y se decidió destinar recursos públicos, procedentes de la privatización, de la renta petrolera y de los impuestos al gasto social (Programa Nacional de Solidaridad: Pronasol), que era la versión populista del neoliberalismo. Desde entonces, los gobiernos se han agenciado el respaldo popular a sus políticas. Y en la 4T, esa modalidad se ha fortalecido, acopiando recursos del Estado para engrosar programas de asistencia social y financiado los proyectos emblemáticos, pero a costa de deteriorar las capacidades institucionales del propio Estado y menguar muchas de las funciones de gestor del desarrollo capitalista. Por lo que es una falacia decir que el Estado neoliberal abandona la función social de protección, pues sigue siendo estratégica y justificada ideológicamente, mediante el liberalismo social y la nueva política social, una especie de neopopulismo. Al tiempo en que apuntala sus funciones como gestor de 
la acumulación de capital y garante de las funciones coercitivas de ley y orden. El impulso de la acumulación por el Estado, mediante la política económica, ha tenido como soporte su política social. En el desarrollismo se justificaba como parte del combate al desempleo y los monopolios, en el neoliberalismo la apertura comercial pretende propiciar un entorno macroeconómico de estabilidad, como el control de la inflación, para garantizar las ganancias empresariales y financieras. Pero la asistencia social del Estado es mínima, puede consistir en la entrega de despensa y una cantidad de dinero, por ejemplo mil 500 pesos mensuales, y con ello se asume que el Estado es la última instancia de defensa de los trabajadores.

\section{El capital sin límites y la naturaleza devorada}

\section{Elegía del despojo y el desarrollismo extractivista}

El progresismo de la nueva ola latinoamericana se caracteriza por ser una gestión estatal del desarrollo capitalista basada en la premisa del crecimiento económico y la distribución social del ingreso para compensar a los más pobres. No plantea cambios sociales ni afectar los intereses del gran capital (una transformación social sustantiva), sino simplemente generar condiciones de inversión para el gran capital privado, sea nacional o multinacional, con el respaldo del Estado, y en ese esquema de coinversión el sector gubernamental es copartícipe de la renta de la tierra derivado de los grandes proyectos extractivistas, y con el government take (lo que le toca al gobierno), vía impuestos, proyecta financiar al Estado, lo que idealmente le permite eludir una reforma hacendaria progresista (con énfasis en 
impuestos progresivos que gravan al gran capital) y, eventualmente, estos ingresos fiscales servirán para redistribuirlos, en parte, mediante programas asistencialistas, que permiten construir una base social de apoyo electoral, que precisa todo gobierno para perpetuarse en el poder. En esa inteligencia, la gestión estatal «progresista» se concentra en los proyectos más rentables, es decir, que en el corto y mediano plazo ofrecen expectativas halagüeñas en los mercados internacionales, particularmente en el caso de las commodities (materias primas, energía y productos primarios), un mercado que, sin embargo, es altamente volátil, inestable y propenso a descalabros, como lo ha demostrado sobradamente el sector energético, minero y alimentario. Esta «vía de desarrollo» no es perdurable, es coyuntural, pero ofrece la posibilidad de no preocuparse por grandes cambios, como generar innovaciones, desarrollos tecnológicos y científicos, rearticulación de mercados internos, valorización del trabajo y protección de la naturaleza. Basta con atraer grandes capitales foráneos.

En México, el proyecto «neodesarrollista» de AMLO se proyecta sobre el tejido de megaproyectos neoextractivistas, una parte de los cuales ya estaba en operación con los gobiernos neoliberales anteriores y otros tantos que se remontan a ideas de gobiernos del nacionalismo priista, pero que ahora se presentan como novedades y se promueven con denuedo para detonar una nueva generación de megaproyectos que no suplen a aquellos sino que los complementan: las zonas económicas especiales (Istmo), el corredor transístmico, las «cortinas de desarrollo», la alianza para el desarrollo y el tren transpeninsular. En la mayoría de los casos se trata de recuperar viejos proyectos olvidados, como el corredor mesoamericano del Área de Libre Comercio de las Américas (ALCA) o la más aún lejana Alianza para el Progreso (Alpro) con Estados Unidos. 
El agente del desarrollo sería, de nueva cuenta, el empresariado nacional, sin reparo en su perfil rentista, estatalista, explotador y depredador, pero no el Estado, que simplemente sería un gestor del desarrollo a la usanza de la nueva gerencia pública, ni la multiplicidad de sectores sociales que configuran la desgarrada economía popular, que simplemente estarían llamados a ser proveedores subordinados de fuerza de trabajo barata y de recursos naturales desregulados. Es el precio del progreso.

Serán veleidades discursivas, pero hasta hace poco, en la arenga lopezobradorista los megaproyectos eran considerados destructivos, formas de acumulación por despojo, pero en las salas palaciegas ahora aparecen súbitamente verbalizados como proyectos necesarios, plausibles, los motores para impulsar la inversión, el crecimiento y el empleo. El concepto negro de megaproyecto cambia de significado bajo la prédica de la $4 \mathrm{~T}$ y ahora es un motor del desarrollo.

No obstante, para crear símbolos negativos, destruirlos y erigirse sobre sus cenizas, la 4T descarrila algunos megaproyectos engullidos con el discurso de «combate a la corrupción». Como una necesidad de autoafirmación, el nuevo gobierno se obsesionó con el Nuevo Aeropuerto Internacional de la Ciudad de México (NAICM), al cual se le dio gran centralidad mediática, cual si fuese el corazón de la nación, para ganar cierta legitimidad en la proyección neodesarrollista del gobierno emergente, pero a cambio se preparaba un portafolio de megaproyectos igualmente extractivistas y explotadores bajo el consabido esquema de inversión público-privado, que tanto han promovido los organismos financieros internacionales y que responden al esquema operativo del neoliberalismo. 


\section{Los proyectos insignia}

No se ha realizado un ejercicio de planeación del desarrollo (el Plan Nacional de Desarrollo es documento ideológico irrelevante) ni se ha diseñado una política industrial ni una reforma fiscal. La apuesta por el rentismo petrolero y el extractivismo de los megaproyectos, aunado a una visión regionalista con una sola zona de desarrollo preferente, el sur-sureste, el enclave petrolero y la región de origen del presidente. En tanto que los empresarios del régimen, que deviene de la parte nodal de la «mafia del poder», es el sector clave del supuesto proyecto transformador.

Los nuevos motores del desarrollo se concentran en un catálogo de megaproyectos de corte extractivista, que le pretenden conferir un nuevo rostro al Estado mexicano, que no es ninguna novedad, sino una recomposición del rentismo.

a) Rentismo energético. El Estado mexicano ha sido, desde los años setenta del siglo pasado, cuando se expande la exportación petrolera, un Estado rentista, dependiente de los ingresos petroleros, asociado a una incapacidad para recaudar impuestos de actividades del capital privado (Farfán, 2011). La obsesión del nuevo gobierno es la renta petrolera, remembranza de una economía petrolizada que diera pujanza al «milagro mexicano» y a una industria nacional —Petróleos Mexicanos (Pemex) - , ahora desmantelada y en quiebra técnica. El gobierno mexicano incurre en la «austeridad» para desmantelar diversas áreas del Estado, generar ahorros y canalizar recursos públicos desmesurados a la maltrecha industria petrolera, buscando además crear refinerías (proyecto Dos Bocas), en un momento de desestabilidad del mercado laboral, donde las guerras comerciales en el seno de la Organización de Países Exportadores 
de Petróleo (OPEP), propiciaron el colapso del sector petrolero mundial, hasta llegar al inusitado escenario de precios negativos del petróleo, muestra fehaciente de la volatilidad del mercado y del sistema de precios, y en consecuencia de la fragilidad del proyecto rentista. La renta petrolera está en decadencia y con ello se desploma el proyecto bandera del lopezobradorismo. Máxime en momentos donde la economía mundial atraviesa por una crisis ambiental de grandes proporciones («cambio climático», negado por gobiernos populistas y extractivistas), que cuestiona seriamente las bases materiales del modo fosilizado de acumulación y postula una reconversión energética a nivel global, que dará al traste con formas anacrónicas de rentismo energético, como es la apuesta lopezobradorista. Desde hace largo tiempo el tránsito del rentismo va de las rentas territoriales a las rentas tecnológicas, donde es más importante no quien detenta la propiedad de los yacimientos sino de las tecnologías y el control de los mercados.

b) Tren turístico y capital inmobiliario en la península de Yucatán. En la península de Yucatán, donde convergen cinco estados del sureste, el proyecto del llamado Tren Maya pretende conectar los principales destinos turísticos de la zona, pasando por la zona arqueológica de Calakmul y las playas de Cancún, en una trayectoria circular de mil 500 kilómetros de longitud, con 15 estaciones, una inversión inicial de 150 mil millones, para lo cual se utilizarán los fondos de fomento al turismo de 7 mil millones de pesos anuales. Pero como es la tónica de la 4T, mientras se concentran recursos en los megaproyectos que son la insignia del gobierno, se disminuyen las partidas a otros, en este caso a los otros centros turísticos y al fomento a la ciencia, la tecnología, la cultura y el deporte. Esta sería prácticamente la única gran obra de transporte, ubicada en una sola región, un enclave turístico. La zona forma parte de un espacio de gestión estatal 
y del capital (Ceceña, 2019). El proyecto del Tren Maya se realizará con un esquema de coinversión: capital privado (90\%) y público (10\%), y serán las empresas privadas las encargadas del diseño, construcción, operación y mantenimiento (Fonatur, 13 de febrero de 2019). De lo cual se deduce que no será un proyecto gubernamental de desarrollo sino un proyecto turístico operado por el capital privado, con respaldo del sector público. La inversión del Tren Maya será preponderantemente privada, en flagrante contradicción con el pretendido cambio de régimen y fin del neoliberalismo. Los ferrocarriles para el resto del país, seguirían iguales, concesionados a empresas mineras y cargueras, sin brindar servicio a la población. Al igual que la desigual red carretera y zonas diversas incomunicadas. El proyecto denominado Tren Maya es una metáfora del gobierno obradorista, es el tren del progreso con división de clases incluida: «El \#TrenMaya será moderno, rápido, puntual y eficiente. Contará con vagones para transportar a los trabajadores del corredor turístico, vagones para clase turista y también camarotes de lujo, carro comedor con gastronomía típica de la región y salón fumador. Todos panorámicos» (Torruco, 14 de agosto de 2018). Pero no sólo se trata de un tren, también se considera un desarrollo inmobiliario, con nuevas ciudades, especulación sobre la tierra y reorganización de los espacios sujetos a la valorización y el rentismo.

c) El Corredor Transístmico de Tehuantepec. La zona preferente de la $4 \mathrm{~T}$ es el sur-sureste del país, región de origen del presidente. Este proyecto tiene más de dos siglos de ser concebido, cuando los españoles, antes de 1819, consideraban la construcción de un canal interoceánico entre el Golfo de México y el Océano Pacífico, pero también se contemplaban como opciones al Lago de Nicaragua y el estrecho del Darién, que fue el que se construyó. En 1980 se propuso el proyecto Alfa-Omega para la región con 
José López Portillo, en 1996 se propuso el Programa Integral de Desarrollo Económico para el Istmo de Tehuantepec con Ernesto Zedillo; en 2001 se propone el Plan Puebla Panamá por Vicente Fox, un proyecto más amplio, con participación de nueve estados y seis países centroamericanos; en 2007 Felipe Calderón retoma la propuesta con un corredor multimodal y en 2013 se replantea con Enrique Peña Nieto con un corredor logístico, industrial y turístico con la participación de China (Torres, 2017). Después el proyecto del Istmo de Tehuantepec, el Sistema Logístico para el Desarrollo Productivo del Istmo, los Parques Eólicos de Oaxaca y el proyecto Puerto América, además de las Zonas Económicas Exclusivas del sexenio pasado. Con la 4T será la sexta ocasión en que se plantea el proyecto de desarrollo regional que pretende que la zona compita con el canal de Panamá, en el simple intercambio de carga contenerizada, pero no existen condiciones para competir. No obstante, la idea sería retomada por el gobierno mexicano en el primer tramo del siglo XIX, con un corredor terrestre con cuatro vías férreas, pero sólo Porfirio Díaz lograría construir un tramo de vías férreas en 1894. El proyecto del corredor transístmico es una idea reciclada, que recientemente, cuando menos, ya había sido propuesta por los cuatro gobiernos anteriores. La 4T resucita esta iniciativa, y según lo previsto en el Plan Nacional de Desarrollo, contempla la creación de zonas libres (incentivos fiscales y no fiscales, con disminución de IVA e ISR, combustible barato) entre Salina Cruz, Oaxaca, y Coatzacoalcos, Veracruz. La inversión inicial sería de 40 mil millones de pesos, según el Proyecto Alternativo de Nación 2018-2024. Se contempla modernizar el ferrocarril, mejorar los puertos de la zona, desarrollar la infraestructura carretera y la red aeroportuaria, y construir un gasoducto para abastecer a las empresas. Se pretende generar un corredor industrial, con 10 parques industriales, con plantas integradas en clústeres. 
d) Aeropuerto militarizado. Para sustituir el NAICM, donde ya se habían invertido 100 mil millones de pesos, que pretende descongestionar al actual aeropuerto Benito Juárez, se atacó febrilmente el proyecto, argumentando corrupción y daño ecológico, para trasladar el proyecto a otra zona, donde también habrá afectación ambiental, despojo de tierras y la obra será concedida al Ejército, el sector privilegiado del sexenio, que también había participado en el proyecto denostado. El nuevo aeropuerto comercial en la base aérea militar de Santa Lucía.

e) Programa «sembrando vida». El programa de reforestación con Felipe Calderón se llamaba ProÁrbol, pero fracasó. Ahora se llama Sembrando Vida y se pretenden plantar 575 millones de árboles, en 1 millón de hectáreas con árboles frutales y maderables, con trabajo temporal para 400 mil jornaleros, con un pago mensual de 5 mil pesos por sembrar 2.5 hectáreas; es un programa forestal que ambiciona cumplir una meta que culmina en la siembra de una determinada cantidad de árboles, pero que no considera una estrategia de cuidado y protección de bosques, la sobrevivencia de los árboles y la recuperación de los terrenos que han estado degradados, dentro de una estrategia de economía agroforestal más amplia, sólo es una estrategia de desarrollo rural, de economía campesina. Según la Secretaría del Bienestar (antes Secretaría de Desarrollo Social), es un programa de bienestar, no un programa ambiental. En su primera etapa, el programa presenta problemas de planeación, pues no está logrando disponer del número de árboles programados, además de que está pervirtiendo el uso del suelo, pues campesinos están quemando sus parcelas, la tala de selvas y bosques, para ser elegibles y entrar al programa y recibir apoyos.

f) Contención de migrantes mediante "cortinas de desarrollo». Si anteriormente el tema migratorio se plegaba a una política de «migración 
y desarrollo» orientada por el Banco Interamericano de Desarrollo (BID) para convertir las remesas salariales en fondos de inversión para infraestructura comunitaria y microproyectos de autoayuda, la agenda migratoria lopezobradorista es abiertamente subsidiaria de la agenda política de seguridad estadounidense y, por añadidura, del discurso xenófobo y neofascista de Donald Trump, quien exige al gobierno mexicano que contenga a las oleadas de migrantes centroamericanos y caribeños desde la frontera sur mexicana, y al mismo tiempo contiene el ingreso de migrantes mexicanos. Mientras se negocia la reconversión del TLCAN en T-MEC, se refuerza la contención de migrantes mexicanos, centroamericanos y caribeños. Contrariando el discurso de que se respetarían los derechos humanos, AMLO se apresuró a crear la Guardia Nacional, un remedo del cuerpo policial militarizado estadounidense, cuya primera tarea ha sido contener las caravanas de migrantes en Chiapas, o en su caso detenerlos y deportarlos. En lo que los militares llaman Plan de Migración y Desarrollo en las Fronteras Norte y Sur, en las fronteras norte y sur de México se apostaron las fuerzas militares y la Guardia Nacional con alrededor de 25 mil 400 efectivos que habría «rescatado» a 78 mil migrantes en ambas zonas en 2019. Asimismo, funge como el «tercer país seguro», recibiendo a deportados centroamericanos desde Estados Unidos hasta que se resuelva su situación migratoria. En el plano diplomático, AMLO ha planteado que sus proyectos de infraestructura y maquilización del sureste mexicano, en el corredor ístmico, las zonas económicas especiales, servirán de barrera de contención a la migración mediante las llamadas «cortinas del desarrollo». En remembranza a la Alianza para el Progreso, solicitó apoyo a Estados Unidos y a los gobiernos de Centroamérica para promover una política de desarrollo regional mediante el Programa de Desarrollo 
Integral: El Salvador, Guatemala, Honduras, México, que proyecta invertir 10 mil millones de dólares anuales durante una década, con la tentativa de crear un espacio económico en la zona e integrar la movilidad humana al desarrollo. Se supone que los países invertirían 25\% de su PIB, del cual 6\% se destinaría a infraestructura, se busca integrar el comercio, crear cadenas regionales, bajar los costos de transferencia de las remesas, fomentar cajas de ahorro comunitario y cooperativas con las «ganancias» de los migrantes. Organizar el mercado laboral, la interconexión eléctrica, un mercado digital, un gasoducto, una carretera turística y la conectividad ferroviaria. Pero para todo ello, tendrían que convencer a Estados Unidos, que sería el gran inversionista. Este proyecto no es nuevo, en el gobierno de Vicente Fox se planteó el Plan Puebla Panamá, en el de Felipe Calderón el Proyecto de Integración y Desarrollo de Mesoamérica, mismo que fue ratificado por el gobierno de Enrique Peña Nieto, pero ninguno ha funcionado. ${ }^{11}$

\section{Reforma del Estado: regeneración presidencialista y gestión capitalista}

El régimen político mexicano, al menos desde los años treinta, ha sido el presidencialismo y se ha desplegado durante el nacionalismo y el neoliberalismo, y continúa vigente con la 4T, más aún, ese es su centro gravitacional: no sólo se reconstruye sino que se profundiza. El poder Ejecutivo es, por definición constitucional, el jefe de Estado, y ejerce las funciones metaconstitucionales de gran legislador, que controla las dos cámaras, el

${ }^{11}$ https://www.youtube.com/watch?v=ks5xxp8Bid0 
poder supremo que impone sus determinaciones al poder Judicial, el que retoma las riendas de las Fuerzas Armadas y controla la agenda pública de los medios de comunicación.

\section{Crisis y restauración del Estado}

El punto de partida es la crisis del Estado mexicano, porque el proceso estatal está fracturado, y existe una preeminencia de intereses de grandes corporaciones, que disponen de mecanismos de gestión y promoción de sus intereses (cabilderos, voceros, analistas), al tiempo en que se dispara la conflictividad social. Los síntomas de la crisis política son la corrupción, la violencia y el deterioro de la representatividad política, donde el sistema electoral no ofrece opciones reales sino dos o tres candidaturas articuladas por el mismo proyecto capitalista neoliberal, con matices y variantes discursivas.

La crisis de representatividad y legitimidad del sistema político mexicano explica la emergencia de Morena y su «hombre fuerte», con gran popularidad, y dominio en las dos cámaras. La crisis del Estado mexicano y del sistema político y del conjunto de la llamada clase política, abrieron paso al triunfo de AMLO y a la formación de un gobierno de coalición que pretende reconstruir la correlación de fuerzas. Dentro del régimen político y la trayectoria de alternancia, el ascenso de AMLO es una respuesta estratégica del poder político y económico para contrarrestar el resquebrajamiento del sistema político y la gestión estatal del desarrollo del capitalismo. Una situación de profunda crisis orgánica, que separa drásticamente a gobernantes y gobernados. Los ciclos de protesta eran múltiples y diversos y no tenían solución dentro del sistema político en decadencia, desacreditado y deslegitimado. Se anunciaba la necesidad de un nuevo 
ciclo dentro de la ola de «transición a la democracia» experimentada en el país desde la alternancia electoral pactada entre priistas y panistas, por la vía de la derecha, para abrir cauces a la izquierda electoral, que ya venía ocupando puestos clave en las gubernaturas, Parlamentos y alcaldías, sin lograr ubicarse en la presidencia de la república.

El problema es que al ganar las elecciones y formar gobierno AMLO no necesariamente toma el poder, y con ello eventualmente la facultad de cambiar el sistema, sino que tiene que comenzar a concentrar poder político. No obstante, el poder del capital y del Estado continúa sujeto al poder del gran dinero (imperio y oligarquía), pero parte con un respaldo popular y alianzas estratégicas con los grupos de poder que puede canalizar para afianzar su gobierno e implementar sus proyectos. Pero eso no significa que la unción del poder político en torno al gobierno y el Parlamento sea posible transformar el Estado para depurarlo de los intereses oligárquicos y reorientarlo al servicio de las clases populares, como un primer paso para implementar un programa de transición. Ello no está en el horizonte político del obradorismo. El Gobierno y el Parlamento dominantes se asumen como una instancia de gestión para «ricos y pobres», es decir, capital y trabajo, pretenden conciliar lo irreconciliable. En ese contexto, AMLO representa la posibilidad de restauración del Estado, pero lo que está por verse es en qué sentido se orientará, si por un cambio de régimen político o simplemente un modo de gobernar.

\section{Presidencialismo}

La ruta de reconstrucción del Estado es la reimplantación del régimen presidencialista, centrado en el Ejecutivo unívoco y unipersonal, como 
instancia controladora de los demás poderes del Estado: Parlamento, Corte y Fuerzas Armadas. Y desde ese mirador privilegiado, tejer nuevas relaciones del Estado con el sistema de partidos políticos y la sociedad civil en general, para recomponer la correlación de fuerzas y afianzar una nueva hegemonía política, sustentada en un bloque de poder (con fracciones de la oligarquía) y bases sociales de apoyo (clases subalternas sujetas a la política oficial), en tanto que se marca una línea divisoria con el bloque opositor al que se busca disminuir, relegar y estigmatizar.

El Estado se concentra en la figura presidencial, que a su vez se asume como condensación o cristalización de la sociedad civil o, más específicamente, encarnación del pueblo a quien dice representar. Una vez afianzado el presidencialismo se desata un proceso de estatalidad, una reconstrucción del Estado como vector de la vida nacional.

El proceso está plagado de contradicciones, pues rememora a un bonapartismo o cesarismo latinoamericano que pretende hacer un juego de equilibrios entre las clases sociales, acorde a una tensa correlación de fuerzas, donde el gobierno es un funambulista que cruza una cuerda floja suspendida en el espacio, como si se elevara por encima de los conflictos sociales y gobernara para todos.

Pero ese bonapartismo equilibrista no es como sus antecesores, antiimperialista, sino que más bien se muestra dócil ante el imperio, aunque determinante y mandón hacia adentro. Pese a su ideología nacionalista, es proimperialista. Hacia afuera, el gobierno de AMLO es abiertamente sumiso ante el poder imperial de Estados Unidos, representado por Donald Trump, como se colige de la ratificación del tratado comercial (TLCAN/T-MEC), la militarización (Guardia Nacional), la represión a migrantes centroamericanos, el pago de la deuda, la colaboración con agencias militares y de 
inteligencia estadounidense y en general la sumisión a la Casa Blanca y el discurso conciliador y amistoso, en un contexto de continua embestida a los mexicanos, los migrantes y el gobierno, además del acoso a gobiernos latinoamericanos, como Venezuela. Pero hacia adentro se dibuja un gobierno centralista, unipersonal, un sistema de gobierno centrado en una autoridad suprema, en la «obediencia ciega» de sus colaboradores y en la fe que se tiene sobre su capacidad personal, a la que se atribuyen rasgos heroicos: «cuarta transformación», «pasar a la historia». Por una parte, hará todos los esfuerzos por apuntalar y sostener la reproducción del capital y, por la otra parte, afianzar su régimen de gobierno con la transferencia de recursos dinerarios a sus bases de apoyo electoral. Esta pauta presidencialista que conjuga neodesarrollismo, neoliberalismo y populismo se torna, en lo inmediato, un proceso fáustico, un proceso de modernización capitalista plagado de contradicciones.

La ruta crítica en la configuración de la fuerza electoral y la formación de gobierno de la $4 \mathrm{~T}$ ha sido tejer alianzas contranatura, la amalgama izquierda-derecha, que se inclina hacia un lado o hacia otro según convenga. El proceso cristaliza con la formación de un gobierno ambidiestro en su ideología y bicéfalo en su conducción: para un lado mira hacia la derecha y para el otro a la izquierda. Es el extraño caso de la presidencia bipolar, pero más que una bipolaridad entre el bien y el mal personificada por un individuo con dos personalidades, el Dr. Jekyll y Mr. Hyde, es una bipolaridad político-ideológica entre el ser populista y el neoliberal, que de un lado aboga por los pobres y del otro por los grandes empresarios. En la versión presidencial figuran dos personajes que enarbolan la ambigüedad ideológica y perfilan la ruta pragmática de la operación política: por una parte aparece el populista, diciendo «por el bien de todos, primeros los pobres», «el pueblo no es tonto, 
no se equivoca» (al votar por él); y, por otro lado, el gestor empresarial Alfonso Romo que dice: «Convertiremos a México en un paraíso de la inversión», que se enfocará en eliminar trabas burocráticas para captar inversión porque sin «crecimiento no hay nada que ofrecerle a los 50 millones de pobres porque tenemos que generar empleo y crear entusiasmo para que México se convierta en el paraíso de la inversión» (Muñoz y Urrutia, 29 de enero de 2020), que certifica un matrimonio con los empresarios y es garante de los megaproyectos y las inversiones del gran capital.

Esa bipolaridad se trasmina aguas abajo, donde, por una parte, las organizaciones empresariales están bien organizadas, hacen activismo político mediante varios frentes y partidos, realizan cabildeo y detentan grandes medios de comunicación; y, por otra parte, el movimiento popular está desarticulado, desorganizado y sin capacidad de incidencia, es engullido por el gobierno emergente y reconfigurado en una entelequia llamada «pueblo», que se reduce al sector militante de Morena, que se activa al fragor de las contiendas electorales y el reparto de posiciones, y de los beneficiarios de los programas de asistencia gubernamental.

Las conferencias matutinas del presidente, las llamadas «mañaneras», se han consolidado como uno de los principales instrumentos del gobierno, porque es un espacio de información que centraliza la agenda pública de discusión con el concurso de la mayoría de los medios de comunicación que transmiten la conferencia y utilizan los dichos para sus espacios informativos, de opinión y debate. También es un espacio de propaganda gubernamental donde se autopublicita, se justifica y se eluden determinados temas. En otro sentido, es un foro de adoctrinamiento para los seguidores del presidente donde se propaga un discurso aleccionador, dirigente; y al mismo tiempo es una arena de golpeteo político contra los adversarios: 
políticos, periodistas, intelectuales, movimientos sociales, defensores de derechos humanos, etcétera. Las mañaneras representan un espacio sui géneris donde el presidente ejerce como jefe de gobierno y en ese momento dicta la agenda pública y las directrices a su gabinete, quienes no hablan por cuenta propia y a quienes se les exige «obediencia ciega»; en tanto que las giras, mítines y actos de inauguración son espacios donde se muestra el jefe de Estado, flaqueado por los secretarios de Defensa y Marina, resguardado por las fuerzas militares. Mediante este mecanismo comunicacional sólo impera una voz y la política se reduce a un ejercicio mediático, un espectáculo, donde el pueblo se convierte en un mero espectador pasivo (los usuarios orgánicos de las mañaneras a través de las redes digitales) de la llamada «transformación» y la alta política palaciega se torna en «politiquería» mediante la confrontación y denostación de los más variados personajes de la vida pública nacional. Por lo demás, se alienta un pseudodebate con resonancia en las llamadas redes sociales digitales, donde se confrontan bandos extravagantes, como si fuera lucha libre política: «chairos» vs. «fifís». Ánimo colectivo se calienta y se torna en un ejercicio irreflexivo, visceral, con una preocupante pobreza conceptual.

\section{Doblegamiento de los otros poderes del Estado}

Pese a que AMLO anunció que no sería el «poder de los poderes», las Cámaras de Diputados y Senadores han fungido como oficialías de parte de la presidencia y los magistrados de la Corte están siendo presionados para acatar las determinaciones presidenciales.

El presidente se erige como el gran elector, una función que ya realizaban sus predecesores, aunque con funciones menguantes en los últimos 
sexenios, los de la llamada «transición a la democracia», dado el régimen de gobierno dividido. Pero AMLO reconstruye esta relación a su favor. Morena obtuvo 37\% de los votos que le permitieron alcanzar una bancada de 247 diputados, entre electos y plurinominales. Pero mediante una argucia de transacción de diputados con sus aliados lograron armar una mayoría artificial al absorber diputados del PVEM y PT, y entonces alcanzaron el número de curules necesarias para alcanzar la mayoría absoluta (250+1) de la Cámara de Diputados, por ello presidirá la junta de Coordinación Política y la Mesa Directiva, además de alcanzar la capacidad de aprobar vía fast track las iniciativas del presidente, excepto las reformas constitucionales, que precisan mayoría calificada (dos terceras partes), lo cual se alcanza al sumar al PT y PES.

La Suprema Corte de Justicia de la Nación es arena de disputa, palmo a palmo. Con la renuncia del magistrado Medina Mora, AMLO propuso a dos ministros, además del sustituto del renunciante y otro extra que anticipa el próximo retiro de un magistrado. Con ello logrará tener los votos necesarios para lograr fallos a su favor, cuyo primer ensayo fue la propuesta de consulta popular para supuestamente enjuiciar a expresidentes, con una votación a favor de 6 a 5 .

La intención de desmontar la «desregulación» bajo la mediación de los órganos autónomos del Estado y recuperar la función regulatoria estatal de conformidad a un determinado proyecto de nación puede tener varios derroteros. Los organismos autónomos de gobierno fungen como instancias de mediación entre el Ejecutivo y los sectores estratégicos, pero debilitan el poder presidencialista. La 4T está interesada en desmontar las instituciones, programas, presupuestos, políticas y mecanismos de mediación entre el Estado y la sociedad civil, para concentrar el poder político en sus manos. Los 
organismos autónomos, ${ }^{12}$ los fideicomisos, ${ }^{13}$ los programas de subrogación de servicios, el financiamiento a organizaciones, los subsidios a sectores productivos, académicos y culturales, entre otras modalidades. Ese tejido político divide, distribuye y amplifica el poder, cuando al presidencialismo lo que le interesa es no tener interlocutores, contrapartes e instancias autónomas, sino reconcentrar el poder del Estado en la persona del jefe del Ejecutivo, supeditar a la sociedad civil a su designio y controlar por completo el dinero público y su ejercicio (Márquez, 2020). El pretexto ideológico es que las formas de mediación política entre Estado y sociedad son neoliberales y corruptas. Pudiera ser el caso, pero los epítetos se lanzan sin estudios, diagnósticos y datos que lo corroboren. Tampoco se incentiva el debate público, el análisis informado y los acuerdos políticos. Se obra por decreto y se aplica a rajatabla.

En la disputa por los organismos autónomos, el presidente se ha apoderado y nombrado presidentes o miembros a su contentillo en la Comisión Nacional de Derechos Humanos (CNDH), la Fiscalía General de la

${ }^{12}$ Los órganos autónomos del Estado son formas de gobierno intermedio: Banco de México (Banxico), Instituto Nacional Electoral (INE), Instituto Nacional de Estadística, Geografía e Informática (INEGI), Comisión Nacional de Derechos Humanos (CNDH), Fiscalía General de la República (FGR), Instituto Nacional de Evaluación de la Educación (INEE), Instituto Nacional de Transparencia, Acceso a la Información y Protección de Datos Personales (INAI), Instituto Federal de Telecomunicaciones (IFT), Comisión Federal de Competencia Económica (Cofece), Consejo Nacional de Evaluación de la Política de Desarrollo Social (Coneval). ${ }^{13}$ Extinción de 109 fideicomisos públicos, que sumaban 68 mil 400 mdp y transferencia de sus recursos y atribuciones al Ejecutivo federal, específicamente a la Tesorería de la Federación, bajo el argumento socorrido de la corrupción (opacidad y discrecionalidad en su manejo, pese a contar con reglas de operación, auditorías y manejo por comités técnicos con cuentas bancarias mancomunadas). Inclusive, algunos generan sus propios recursos o perciben donaciones. Más de la mitad pertenecían al Conacyt, en materia de investigación científica. Otros se refieren a desastres naturales, promoción del deporte de alto rendimiento y protección a defensores de derechos humanos y periodistas (Segob, 2 de abril de 2020). Pero no se extinguieron los fideicomisos de aduanas señalados por irregularidades por la Auditoría Superior de la Federación y la Sedena para compra de armamento por 100 mil mdp. 
República (FGR), el Tribunal Electoral del Poder Judicial de la Federación (TEPJF), la Suprema Corte de Justicia de la Nación (SCJN). Al tiempo en que tiene una confrontación abierta o velada con el Instituto Nacional Electoral (INE), el Instituto Nacional de Estadística, Geografía e Informática (INEGI), el Banco de México (Banxico), el Instituto Nacional de Transparencia, Acceso a la Información y Protección de Datos (INAI), entre otros.

Otro sello de identidad de la república $4 \mathrm{~T}$ ha sido el militarismo. Un movimiento estratégico ha sido pactar con las Fuerzas Armadas, tanto para disuadir la posibilidad de un golpe de Estado como para afianzar su poder político frente a sus adversarios, opositores. El costo ha sido muy elevado, el país se ha militarizado como nunca. Las Fuerzas Armadas ejercen funciones militares, como es su cometido, pero también funciones de policía, administrador de puertos y aduanas, agente inmobiliario y constructor y beneficiario del proyectado aeropuerto Felipe Ángeles. Han sido receptores de una tajada fabulosa del presupuesto público, en tanto que a otros sectores, como educación, salud, ciencia, cultura, tecnología y campo, se les castiga con el flagelo de la austeridad.

La carta de navegación del régimen no es, como podría suponerse, la Constitución, sino la cartilla moral de Alfonso Reyes y el discurso moralista cristiano que propala el presidente a la menor provocación. Antes que cambios constitucionales de gran calado para asentar una agenda política de transformación social se difunde la moralidad burguesa y la religiosidad evangélica, con lo cual el carácter laico del Estado se pone en predicamento (Barranco y Blancarte, 2019). 


\section{Reestructuración burocrática y reproducción del capital}

La depuración de la esfera burocrática atiende a la necesidad primaria de colocar a los cuadros políticos de Morena y desplazar a los funcionarios de los gobiernos anteriores, pero preservando determinados sectores administrativos y tecnocráticos necesarios para el funcionamiento de la maquinaria gubernamental. No obstante, se implementan ajustes tales como la disminución de salarios de la alta burocracia, pero también el despido de personal y la precarización del trabajo del sector público, en un contexto más amplio donde priva la superexplotación laboral; el recorte de presupuesto, desaparición de áreas y programas y la concentración de recursos hacia sectores burocráticos y operativos preferentes, los que están a cargo de los proyectos insignia; además de la desaparición de los delegados federales con sus dependencias y burocracia, para nombrar a un superdelegado federal en las entidades y un ejército de brigadistas, los «siervos de la nación», agentes del gobierno que cumplen funciones logísticas y proselitistas, entre otras. En cambio, se han desechado otras propuestas, como la descentralización mediante el traslado de 25 dependencias de la Ciudad de México a las entidades federativas.

La reestructuración burocrática tiene el doble cometido de reforzar el presidencialismo reconstruido y de orientar la maquinaria a la reproducción del capital y a la formación de una base social de apoyo al gobierno. hacia ello se orienta el diseño presupuestal, la concentración del dinero público y la reorientación de programas.

El gobierno de la 4T pretende ser de «equilibrios», pero es una muestra de las «contradicciones sociales». Bajo la retórica de la reconciliación y la pretendida noción de gobernar para todos subyace la contradictoria 
formación del gobierno y su gabinete es acorde a las exigencias de reproducción del capital y de ampliación de los espacios de poder del gobierno en turno. Pero no puede eludir la atracción de las contradicciones sociales en su seno: la derecha empresarial y la tecnocracia neoliberal $v$ s. movimientos sociales y la superviviente izquierda electoral, con la capitanía de la derecha empresarial y la comparsa de la izquierda electoral. En la reconfiguración de la nueva hegemonía político-cultural y de la clase dirigente, la izquierda histórica se subordina y desdibuja.

Alfonso Romo y en general la 4T impulsa la formación de «políticos genéticamente modificados», es decir, la atracción de contradicciones en el seno de la alta burocracia estatal con un ADN ideológicamente híbrido. Este es un rasgo profundo de las contradicciones dentro del gabinete y las secretarías del gobierno emergente, donde cohabitan funcionarios con posiciones encontradas en temas que les competen. La alta burocracia está comandada por sectores de la derecha empresarial que hacen cortocircuito con sectores de izquierda.

Frente a la dominante figura presidencial, de corte caudillista, el gabinete es de muy bajo perfil, guarecido a la sombra del líder. Está compuesto por una amalgama de viejos políticos y burócratas, emanados de gobiernos anteriores y representantes de sectores oligárquicos, y de jóvenes inexpertos, hijos de amigos personales del presidente. Es un gabinete que tiene una edad madura, con promedio de 60 años, el presidente tiene 66 años, no tiene mucha consistencia ideológica y es pragmático. El presidente no tiene resquemores en afirmar que gobernar es una tarea fácil, que no requiere de mucho conocimiento ni experiencia, no es un arte, no es una actividad de expertos, sólo se requiere de sentido común. Para formar su equipo a lo sumo se necesita « $99 \%$ de honestidad y $1 \%$ de experiencia». Eso 
sí, exige de ellos «obediencia ciega» y los que osan criticar son despedidos o renuncian, aunque a la vieja usanza se pretexta que dejan el cargo por «problemas de salud».

Cualquier gobierno necesita propiciar la profesionalización de la función pública, pero el presidencialismo es unipersonal y unívoco, donde los criterios se alinean a los requerimientos del líder político, aún sobrepuesto a la realidad o las necesidades sociales. En ese marco, y ante la necesidad de autoafirmación y de proyección política para el futuro inmediato, no faltan los funcionarios que se asumen como expertos o como intérpretes de los sentimientos de la nación que piensan saberlo todo sin conocer el funcionamiento del Estado y nuevos funcionarios que consideran que todo lo anterior no funciona y que por ser ellos mejorarán las cosas sin tener la profesionalización o conocimiento mínimo indispensable.

\section{Nuevo bipartidismo}

El espectro del sistema político se reconfigura con el triunfo de Morena en dos grandes frentes político-electorales, que responden inicialmente a la crisis de representación de los partidos y los políticos profesionales, pero sustentados en la popularidad de gran líder mesiánico y no en un renovado sistema de partidos.

En primer lugar, figura el partido de la reforma, representado por Morena y sus partidos satelitales: PES, PT, PVEM y los nuevos partidos Redes Sociales Progresistas (RSP) y Fuerza Social (FS). Esta es la coalición «Juntos Haremos Historia», con mayoría en las cámaras legislativas, pero que en realidad actúan como oficialía de partes de la presidencia y Morena ha sucumbido a la organización parapartidista orquestada por la misma 
presidencia a partir de los operadores electorales en las superdelegaciones federales y las brigadas de los «siervos de la nación». Morena, al final de cuentas, es un partido mesiánico.

En segundo lugar, está el partido del orden y el dinero conformado por la coalición del PRI, PAN y PRD, los partidos que venían cogobernando en las últimas administraciones federales y que resultaron ampliamente derrotados en los últimos comicios por López Obrador y su coalición electoral. En un lugar marginal se ha colocado Movimiento Ciudadano, que anteriormente estaba coaligado con Morena y después con el PRI, PAN y PRD, para finalmente figurar de manera aislada.

Es sintomático que esta constelación partidaria sea un producto de la «transición a la democracia» del régimen neoliberal-presidencialista, que tiene un gran ausente, el partido de la revolución o la transformación social, pues no existe ningún partido oficial de izquierda radical o revolucionaria, y por consecuencia ninguna representación parlamentaria ni gubernamental. Las dos grandes formaciones políticas han compartido gran parte del «consenso neoliberal» $y$ han sido cogobernantes en al menos los últimos tres sexenios (Márquez, 2018).

Con todo, el gran riesgo es que AMLO se erija como el poder supremo, merced a un presidencialismo recargado, donde por una parte se asuma como la encarnación misma del Estado, que controla todas las esferas del poder político, sus recursos y mecanismos de decisión, y que por otra parte se arroje la única y genuina representación del pueblo y que por su boca se emita la voz popular y los sentimientos de la nación. 


\section{Premisas de gobierno}

\section{Ortodoxia en finanzas públicas y camisa de fuerza}

Los economistas ortodoxos defienden el neoliberalismo como un modelo que ha generado crecimiento económico en los últimos 30 años, estabilidad económica y salida a la crisis económica de 1994-1995, aunado a estabilidad política que engendró la alternancia electoral o la llamada transición a la democracia. Sin embargo, las reformas «neoliberales» se hicieron para salvar al Estado en crisis. Inclusive, desde 1976, los presidentes «populistas», vilipendiados por los neoliberales, habían pactado las reformas con el Fondo Monetario Internacional (FMI), debido a la inviabilidad de las finanzas públicas. Sin embargo, el auge petrolero experimentado entonces permitió una postergación de tales reformas, pero a la postre precipitó al país en una profunda crisis, la cual sería gestionada con la imposición, en definitiva, del modelo neoliberal. Para ello se implementó un programa de «rescate» de 20 mil mdd del gobierno de Estados Unidos, de 17 mil mdd del FMI y de 10 mil mdd del BID, lo anterior para evitar un crack global. De este modo se convirtieron más de 500 mil mdp de deuda privada en deuda pública, la cual ha seguido una espiral ascendente, perpetua, hasta nuestros días. El Estado mexicano sigue siendo tributario del capital financiero. Hay que pagar la deuda, sin cuestionar su ilegitimidad, por encima de cualquier otra prioridad social: «El costo financiero de la deuda pública en 2019 será de 750 mil millones de pesos, 120 mil millones más que en 2018». Derivado de esa sujeción se implementa una férrea disciplina en las finanzas públicas para evitar que el gasto público supere a los ingresos y a partir de ello implementar recortes al presupuesto mediante la llamada austeridad. 
Cubierto con el paraguas neoliberal, el gobierno de la $4 \mathrm{~T}$ ha insistido en no contraer más deuda, aunque sí lo haya hecho y además presente los mayores niveles históricos de deuda, producto del bajo crecimiento, la baja recaudación y la devaluación del peso, que afectan a las deudas ya contraídas. Sin considerar la nueva deuda por el incumplimiento de contratos. En este enfoque prevalece un falso criterio financiero que confunde a la sociedad como si fuese una familia y al Estado como un paterfamilias: mientras que una familia que contrae una deuda está obligada a su devolución y en tal medida condiciona su ingreso, pues no tiene mayor margen de maniobra, un Estado dispone de más recursos: recaudar más impuestos, imprimir dinero fiduciario para pagar deudas a los acreedores, generar ganancias de las empresas públicas, tomar parte de la renta por concesiones de sectores públicos, contratar deuda, recaudar ganancias del capital ficticio y aumentar precios y tarifas de servicios públicos.

En la administración pública el problema no es tanto cuánta deuda se puede adquirir y cuántos ingresos recabar sino cómo gastarlo e imprimir dinamismo económico y social, si se promoverá la actividad productiva y la generación de valor con mecanismos de redistribución o sólo se distribuirán recursos manteniendo esquemas de gasto improductivo, como el asistencialismo basado en la austeridad y el rentismo estatal. Reducir el gasto estatal atendiendo al dogma neoliberal tiene consecuencias en el ingreso (lo cual no sucede así con las familias). Si el Estado mantiene su soberanía monetaria, es técnicamente imposible que quiebre, salvo por una decisión política. Así, pues, el problema radica en la pérdida de soberanía monetaria y estar a disposición de los mercados financieros internacionales, donde una tasa de endeudamiento menor de un país periférico puede representar un pago de intereses superior (p. ej., Estados Unidos tiene una deuda pública de más de 100\% del PIB pero abona menos de 2\%). 
AMLO heredó la deuda pública más alta de la historia de México: 9.9 billones de pesos, equivalente a 42.4\% del PIB (casi 80 mil pesos per cápita), pero pese al discurso oficial de no aumentar la deuda, contener la inflación y estimular el crecimiento económico, en realidad ha sucedido lo contrario.

La primera deuda contraída por AMLO fue derivada de su acto inaugural de gobierno, la cancelación del Nuevo Aeropuerto Internacional de la Ciudad de México (NAICM) por 60 mil millones de dólares pagaderos en 19 años, el cual será pagado a las empresas contratistas con cargo a los usuarios de los aeropuertos, mediante el impuesto de la Tarifa de Uso del Aeropuerto (TUA), una de las tarifas más altas del mundo, recurso que se emplea para el mantenimiento y expansión de instalaciones y que ahora se desviará para cubrir deuda. Pero también se emplearán recursos fiscales extraídos del común de los contribuyentes.

Además, el gobierno adquirió una deuda del Banco Mundial por 2 mil 130 millones de dólares en los primeros 18 meses de gobierno de AMLO. Un crédito del Banco Mundial por mil millones de dólares estaría etiquetado para atender la contingencia epidemiológica (Banco Mundial, 2020), pero el gobierno de México anunció que no lo utilizaría para ese propósito. En lugar de ello se destinó a funciones financieras, como imprimirle liquidez al sector financiero y la bancarización de jóvenes, no para atender las crisis económica y social de la COVID-19.

Aunado a ello, factores como la caída del PIB de -8.5\%, que altera negativamente la relación de endeudamiento, y el aumento de la inflación de 6.4\% según datos oficiales, la devaluación del peso frente al dólar, la baja recaudación fiscal y la política de recorte presupuestal, además de los estragos de la pandemia de la COVID-19, se ha registrado un crecimiento global 
de la deuda de 8.6\%. En su segundo año de gobierno la deuda alcanzó los 12 billones de pesos, que representan 52\% del PIB.

Por si fuera poco, el gobierno enfrenta una caída estrepitosa en los precios del petróleo. Los ingresos del petróleo se derrumbaron 41.3\% en el primer trimestre de 2020, con 208 mil 810 millones de pesos debajo de lo programado, pese a un incremento de la producción de 1.7\% anual (SHCP, 2020), debido a la caída de los precios internacionales del crudo y del consumo de hidrocarburos y combustibles, con la consecuente caída en los ingresos presupuestales de 3.7\% anual, lo cual sólo es mantenido por el cobro de impuestos. Previsiblemente, esta tendencia será más acusada con la caída de la actividad económica mundial asociada a la pandemia y la quiebra de empresas de aviación, transporte terrestre, turismo, etcétera. Paradójicamente, la apuesta principal de la $4 \mathrm{~T}$ es el sector petrolero, que está expuesto a juegos especulativos, inestabilidad en las cotizaciones y la transición energética en curso (sustitución paulatina de hidrocarburos por electricidad).

AMLO proyectaba un crecimiento de la economía de $2 \%$, pasar a $4 \%$ hasta llegar a 6\%; la realidad es que no ha crecido sino decrecido la economía. Asimismo, imaginaba que la estrategia de combate a la corrupción significaría un ahorro de 500 mil millones de pesos, pero esa meta no se ha logrado. Además, prometió no incrementar impuestos, pero en realidad sí se han subido y creado nuevos, como a las plataformas digitales y el uso de internet, pero sin hacer una reforma fiscal progresiva, donde se cobre a las grandes fortunas y grandes capitales.

En México la carga tributaria es muy baja, representa 16\% del PIB, cuando el promedio en los países de la OCDE es de 34\% (p. ej., en Noruega llega a 48\%, mientras que en Estados Unidos es de 27\%). Siguiendo la 
consigna neoliberal, AMLO ha dicho que no se crearán nuevos impuestos, pero se implementan varias estrategias para aumentar la recaudación, en el contexto de una economía en depresión. Se pagan más impuestos por gasolina y bebidas azucaradas, aumentaron los impuestos a los cigarros (crecieron 41\%). También las plataformas Netflix y Airbnb ahora cobrarán IVA a los usuarios: la economía digital representa un 5\% del PIB. Además de que se combate la evasión fiscal y se cobran adeudos a empresas y pequeños contribuyentes. Pese al ambiente recesivo asociado a la pandemia, el gobierno ha logrado un incremento en la recaudación, en parte por el cobro a grandes empresas, el combate a la defraudación fiscal y la prohibición de las condonaciones, pero también a los nuevos impuestos e incremento a los ya existentes (véase López, 15 de mayo de 2020).

En un contexto real de decrecimiento, o de franca depresión económica, desempleo y mayor pobreza, esa política resulta, a todas luces, regresiva. Cubrir el déficit fiscal con nuevos impuestos e incremento a los existentes, termina por gravar al consumidor final y deja indemnes a las grandes fortunas y capitales. Para cubrir el déficit fiscal, el gobierno persigue la estrategia de incrementar subrepticiamente los impuestos, ahorrar dinero público mediante subejercicios en el gasto, hacer ajustes drásticos que incluyen recortes y despidos, restringir el gasto en sectores estratégicos como salud, educación, guarderías, y reorientar el gasto a programas preferentes (como resucitar a Pemex, lo que amerita pagar su onerosa deuda y refinanciar a la empresa, junto con proyectos de refinería, entre otros).

El modelo neoliberal de los gobiernos priistas y panistas ha dejado un escaso margen de maniobra en el presupuesto, la mayor parte se canaliza hacia deuda y gasto corriente (salarios, prestaciones). Ese marco no se modifica con la $4 \mathrm{~T}$ y tentativamente se restringe. Debido a la interrelación 
entre aumento de la deuda pública, decrecimiento económico, baja recaudación y austeridad o ajuste presupuestal, el gobierno tiene un margen de operación del presupuesto muy bajo: 20-15\% o menos $(10 \%) .{ }^{14}$ Se recorta el gasto público (austeridad) y a cambio se redistribuyen los ingresos tributarios de manera más restringida a las instancias de gobierno y sus programas. A la contracción del gasto público le sigue el pago preferente de servicios de la deuda y obligaciones gubernamentales (tenedores de valores de NAICM), incremento a la militarización, reducción al sector educación, ciencia y tecnología y cultura.

Aún dentro de los márgenes del reformismo, el nuevo gobierno se resiste a una reforma fiscal progresiva (que paguen más impuestos los que reciben mayores ingresos, el capital). La recaudación es apenas 0.8 puntos más que en 1983, cuando inició el periodo neoliberal. No se busca generar una fuente alterna de ingresos fiscales (p. ej., renta petrolera, no se revertirá la «reforma energética»). La respuesta anticlimática está en el combate a la corrupción, la austeridad, el cierre de programas, el recorte al presupuesto, el subejercicio, la disciplina fiscal, es decir, las consabidas recetas neoliberales para desangrar a determinados aparatos del Estado, el trabajo y los derechos sociales.

${ }^{14}$ Puesto que 8 de cada 10 pesos del gasto está «etiquetado» como gasto programable para el pago de la deuda pública (incluye Fobaproa-IPAB), pensiones, la nómina de la burocracia (además de maestros, médicos, enfermeras, policías y Fuerzas Armadas) y los servicios personales del aparato del Estado, y 2 pesos quedan disponibles para los programas del nuevo gobierno. El margen de maniobra se reduce a 5\% si se consideran otras partidas, como pago de subsidios, los rubros de justicia, legislación, protección ambiental, transferencias y aportaciones, además del gasto de operación. 


\section{Arenga anticorrupción y ajuste estatal}

El discurso anticorrupción no es de por sí antineoliberal, sino que está enraizado en la ideología neoliberal: se trata de un ataque a la esfera de lo público y lo estatal, señalado como corrupto e ineficiente con el propósito de desmontarlo y reconvertirlo hacia la esfera del mercado, donde, se supone, priva la eficiencia y la competitividad. Logrado esto, los brotes de corrupción que perviven en el Estado se combaten con medidas como desregulación y adjudicación de obras a empresarios privados, transparencia y rendición de cuentas, y discursos y más discursos, para que continúe la economía de mercado.

La política anticorrupción es el eje central del discurso electoral lopezobradorista (López, 2017) y se erige como el eje del gobierno. Pero las anteojeras de AMLO detectan corrupción por doquier, no así explotación, dominación y despojo. La idea de que el Estado es una mafia del poder, por corrupta, no porque sea el comité de la burguesía nacional, es la noción del lopezobradorismo.

El discurso anticorrupción de AMLO proviene de cifras atribuidas al Banco Mundial, donde se emprende un ataque contra el Estado, para minar su función social y económica, y resguardar su función de guardián del orden, la ley y la promoción de los valores liberales: mercado, capital, empresa. También de ese organismo proviene el diagnóstico en el cual se basaron la campaña y las primeras intenciones gubernamentales del lobezobradorismo, según el cual la corrupción política significaría 9\% del PIB, que representaría 20\% del presupuesto nacional, ${ }^{15}$ recursos que recuperados

${ }^{15}$ En este diagnóstico han coincidido tanto AMLO, que fue su bandera política, como los voceros del sector empresarial: Instituto Mexicano de la Competitividad, el Banco Mundial y 
se canalizarían hacia las grandes obras de gobierno y los programas sociales, sin necesidad de impuestos progresivos que graven al capital, ni de contratar más deuda, ni mayores cambios, se trataría de un trasvase de recursos supuestamente preexistentes de sectores corrompidos hacia obras bondadosas. Pero tan sólo tomar las riendas del gobierno se repara en que tales recursos no tienen una existencia material, real, como para hacer esa transferencia virtuosa, sino que se requerirá el adelgazamiento del aparato estatal, mediante una austeridad a rajatabla, que destruye capacidades institucionales, suprime programas, despide trabajadores, reduce presupuesto a sectores importantes, todo para transferir esos recursos a los proyectos bandera en infraestructura y asistencialismo, a costa de autofagocitar el aparato público.

En tanto que los artífices de la corrupción política que fueran señalados como enemigos del pueblo para fines electorales («la mafia del poder») son perdonados, bajo una amnistía, que presupone un pacto de complicidad, acuerdos tras bambalinas, que permitieron el reconocimiento del triunfo electoral en aras de restañar la profunda crisis del Estado mediante una alternancia pactada. Al declarar anticipadamente la amnistía a los corruptos políticos y empresarios («borrón y cuenta nueva»), se renuncia a trastocar las estructuras de poder y se empeña en moralizarlas (como habían presupuesto gobiernos anteriores) y precarizarlas.

Es llamativo el hecho de que los actos de corrupción señalados que han sido cometidos por el gobierno en funciones no han sido investigados

la OCDE. Sin embargo, la verificación de tales cifras ha sido un galimatías, porque la misma fuente a la que se le atribuye el dato, el BM, aduce no disponer de un estudio, sino que otros organismos y políticos atribuyen ese dato a ese organismo, uno de cuyos voceros retomó las notas de segunda mano para enunciar esa cifra. Lo cual se ha convertido en un marasmo sin sustento, pero una eficaz bandera política (Paredes y Ávila, 2018). Aún así, el gobierno en funciones sigue insistiendo en esa cifra (Notimex, 14 de mayo de 2019). 
ni sancionados, sino por el contrario, solapados y pasados por alto. $\mathrm{O}$ actos que se supone ya no sucederían, como las adjudicaciones directas a empresarios socios del gobierno, la integración al gabinete de funcionarios con dudosa reputación, etcétera.

El discurso anticorrupción es muy socorrido entre los populistas, que contraponen al pueblo bueno con los políticos corruptos. La política se presenta como un ejercicio delincuencial de enriquecimiento, fraude, tráfico de influencias, demagogia, simulación, donde prima la máxima priista: «Un político pobre es un pobre político». Y qué mejor que un político que se forja como un símbolo de honradez, moralidad y lenguaje llano para encarnar el sueño de revancha de la masa contra los políticos, siendo un político que trabaja y se ha formado como político profesional, dentro de esas prácticas que dice cuestionar. Sin embargo, la variopinta coalición política de la 4T, incrustada en el gobierno, el Parlamento y otras esferas del poder público no son extraterrestres ni almas de la caridad, son políticos profesionales reciclados, de todos los partidos políticos (del PRI, PAN, PVEM, PRD) y de grupos operadores y tecnócratas del modelo neoliberal que se dice combatir. Gran parte de ellos han sido gestores del neoliberalismo y han ocupado puestos de poder y saltado oportunamente de partidos para acomodarse en la administración pública o las curules, y se acomodan sin remilgos a los proyectos y discursos de los gobiernos en turno. Y siempre están operando para saltar a la siguiente posición. Así es la política profesional y no ha cambiado.

\section{Corrupción política}

El tema de la corrupción política no sólo se refiere al enriquecimiento ilícito de los políticos sino a la degradación de la política, la democracia y la 
ética política. Algunos altos funcionarios han sido señalados por enriquecimiento inexplicable o por alterar sus declaraciones de propiedad, para eludir su imagen como funcionarios ricos en un gobierno pobre y una sociedad pauperizada. ${ }^{16}$

En tal sentido, se puede cuestionar el reciclamiento de la vieja clase política (una suerte de kakistokracia) que figura como la gestora y operadora del gobierno de la 4T, donde figuran grandes empresarios y sus grupos de interés o incidencia política (CMN, etcétera), líderes sindicales corporativistas y políticos afectos a la demagogia, el cambio de partido y la búsqueda compulsiva de posiciones de poder.

La corrupción política también se decanta por el fetichismo del poder y más todavía cuando aflora el presidencialismo y el mesianismo. La formación del gobierno lopezobradorista tiene un vicio de nacimiento, que puede considerarse un acto de corrupción política en el sentido dusseliano, no en el sentido de enriquecimiento ilícito, sino en dos sentidos, el primero en tanto que el líder máximo se asume como tal, la voz cantante, que «cree que ejercen el poder desde su autoridad autorreferencial (es decir, referida a sí mismo), su poder se ha corrompido» (Dussel, 2006: 13-14), el poder reside en quien detenta la autoridad, mejor ejemplo no puede haber que el presidencialismo exacerbado de AMLO; y en segundo lugar porque hay una completa deformación en el gobierno, que dice ser de izquierda, pero está dominado por cuadros políticos de derecha que persiguen objetivos de esa ideología. Es una corrupción originaria que asume

${ }^{16}$ Tales son los casos de las multipropiedades inmobiliarias de Bartlett, Sánchez Cordero y Eréndira Sandoval. O la entrega de dinero, presumiblemente de un gobierno local, al hermano del presidente para financiar la campaña electoral, entre otros que han salido a la luz pública. 
la forma de «fetichismo del poder», donde el Estado configura al pueblo, esa entelequia que a su vez, presumiblemente, le confiere la legitimidad y el poder.

Por añadidura, Morena como nuevo líder del sistema de partidos no se ha configurado del todo como un partido político, pues continúa con las viejas prácticas del partido de Estado: formación de mayorías artificiales, promoción de partidos satélites, ausencia de debate político sobre los problemas nacionales y sus alternativas, sumisión al presidente. Los sectores medios se siguen moviendo en los terrenos de la ambigüedad política, a favor y en contra del gobierno emergente, buscando obtener beneficios en los movimientos y ajustes (intelectuales, académicos, científicos, estudiantes, profesionistas). Finalmente, las clases populares están a la cola de los acontecimientos y quedan como espectadores pasivos de la trama del poder (trabajadores, desempleados, marginales, pobres).

Un signo de corrupción política es la transformación de «políticos orgánicos» con determinada congruencia teórica, ideológica y política, que pudiera identificarse con la izquierda y las causas populares para mutar en "políticos genéticamente modificados», que cambian sus principios, ideología y ética para adecuarse a las exigencias inmediatas, las nuevas condiciones, que les permiten colocarse en las esferas de poder y abrazar cualquier proyecto político-electoral, obviando contradicciones, ambigüedades, en pos del éxito y los privilegios consustanciales a la función pública, gubernamental y parlamentaria.

Otro signo de la corrupción política de la 4T es la destrucción del Estado laico con la intromisión de las Iglesias evangelistas en el Palacio Nacional y las recurrentes alusiones del presidente al cristianismo, la Biblia y los actos litúrgicos. La alianza de Morena con el PES, un partido evangelista. 
La entronización de la moralidad religiosa y del conservadurismo societal fundado en los valores y la familia como fundamento de su cruzada por la regeneración moral de la vida pública.

El fetichismo de la hegemonía es también un síntoma de degradación política, en tanto el proyecto político carece de un genuino sujeto colectivo político de la transformación social en el que estén organizados, representados y activos los trabajadores de los diversos sectores y grados de calificación, que son la mayoría social que genera el valor con el cual la sociedad se moviliza y de lo cual el Estado abreva para subsistir e imponer sus determinaciones. Cuando el sujeto del cambio es el gobierno y su entramado político estatal, a expensas de las mayorías sociales, lo que cristaliza es un régimen estatalista, que suplanta al sujeto social. Y desde esas alturas, en lugar de concientizarse a la población para formar un nuevo sujeto de la transformación que haga efectivamente historia, se le subordina, coopta. Esta es una transformación estatista, un cambio social pasivo, blando, reformista.

Para convertirse en proyecto de transformación social, no es suficiente suponer un cambio de instituciones, por ejemplo la moralización, austeridad, militarización y depuración al que ha sido sometido el Estado, sin variar su función como capital colectivo, como administrador de los intereses del capital colectivo, sino que se trata de impulsar la emancipación social, no mediante una entelequia llamada pueblo sino mediante la concientización, organización y activación de un poder popular fundado en los creadores de la riqueza, los trabajadores. Un sujeto consciente, no una base electoral subordinada a las dádivas. Y no se trata de imponer una línea verticalista y autoritaria desde el Estado sino promover la independencia y autonomía, una formación político-cultural de clase. 
¿Austeridad para quién?: el pobrismo como premisa

La política de austeridad en realidad es un dispositivo neoliberal (Blyth, 2014; Stuckler y Basu, 2013). Pero se presentan con un halo de validación con una doble connotación: una austeridad «republicana» para el Estado (neoliberalismo encubierto: austeridad/ajuste) y una austeridad franciscana para los individuos (apología de la pobreza).

Las políticas neoliberales anticorrupción se complementan con las políticas de austeridad y ajuste que se traducen en el recorte del gasto social, educación y salud, el despido de trabajadores del sector público, la cancelación de programas, el recorte presupuestal, el cierre de servicios públicos y la privatización de bienes y servicios públicos.

Bajo la norma de la austeridad neoliberal, el diseño presupuestal está regido por el dogma de la disciplina fiscal (austeridad/ajuste), la economía acorde a las «señales del mercado», es decir, a favor de los monopolios, la militarización y la política del liberalismo social, el asistencialismo.

El desmantelamiento del Estado en cuanto a desvalorizar el valor del trabajo del sector público: precarizar las condiciones de trabajo, disminución de salarios y prestaciones, despido de trabajadores, y la propagación de la retórica neoliberal de que los derechos sociales adquiridos son privilegio que hay que desterrar y las luchas sociales son chantajes; reducción de presupuestos a programas, disminución de bienes públicos, privatización de recursos del Estado; Austeridad, sinónimo de desempleo, precarización laboral, desmantelamiento del Estado, ataque a sindicatos (derechos como «privilegios», luchas como «chantajes»). Menos inversión, precarización del sector público, traspaso de activos al sector privado, otorgamiento de concesiones, inversiones público-privadas, etcétera. 
El estilo personal de gobernar austeramente es persuasivo para la masa social: desiste de vivir en los Pinos, pero se hospeda en el ostentoso Palacio Nacional; no usa el Estado Mayor Presidencial, pero es resguardado por una guardia personal de las Fuerzas Armadas; realiza mítines públicos en los estados, pero cuando el escenario es adverso se recluye en las instalaciones militares para pronunciar sus arengas; renuncia al avión presidencial, pero usa vuelos comerciales acumulando millas como viajero frecuente; reduce $40 \%$ el salario presidencial y lo fija como salario máximo de la alta burocracia; disminuye el presupuesto del Congreso y Corte, pero concentra recursos en proyectos a costa de devastar el entramado institucional que no está alineado a su dominio. Estas medidas contienen un carácter efectista y simbólico, que refuerza un estilo personalísimo de gobernar a tono con la narrativa de la honestidad, pero al mismo tiempo es una perversa justificación para imponer la austeridad neoliberal, que ya se viene implementando décadas atrás: recorte a presupuesto, despido de trabajadores, supresión de programas, privatización de activos públicos, etcétera. Paradójicamente, aquí se comete un acto de corrupción política: el fetichismo del poder (Dussel, 2006), es decir, la presunción de que un individuo encarna el poder popular y que se atreve a imponer su ideología y su estilo de vida al conjunto de la nación, como si fuese un gran patriarca, el nuevo padre de la patria.

Uno de los efectos inmediatos de la austeridad ha sido la desescolarización. El Estado mexicano tiene una enorme deuda social no reconocida en materia de educación superior y en todos los niveles. En términos generales, la universidad pública en la picota, pero la respuesta es ambigua: por una parte, acotar a las universidades estatales con presupuestos austeros (10 universidades públicas estatales en profunda crisis presupuestal) y la 
consigna de «hacer más con menos», el mantra de la austeridad neoliberal lopezobradorista, que no es sino una versión populista de los programas de ajuste que se han implementado desde los ochenta; y, por otra parte, anunciar un programa incierto de creación de 100 universidades para 130 mil estudiantes con beca, comedor y albergue, que deberán estar «necesaria y estrechamente» al servicio del mercado laboral de diversas regiones del país, donde se impartirá sólo una carrera, con un presupuesto de mil millones de pesos. Es un plan para duplicar la matrícula de las universidades públicas.

La salud pública se caracteriza por su precariedad. En México, 32.9 millones de mexicanos, es decir, 26\%, no tiene afiliación a ningún servicio de salud (INEGI, 2020), sólo 2.8\% tiene acceso a salud privada. En el IMSS está 51\% de los inscritos, 35\% en el Insabi. No obstante, la afiliación sólo es un dato administrativo que no refleja el acceso real a los servicios de salud, que por lo común suelen estar saturados, con desabasto de medicamentos, y una franja importante de derechohabientes tiene que recurrir a consultorios privados. El gobierno de la $4 \mathrm{~T}$ se había propuesto ofrecer, a estas alturas, servicios de salud universal, incluso homologando el sistema de salud noruego, lo cual dista mucho de alcanzarse. Más bien ocurre lo contrario, hay una desinversión en el sector de salud pública. Se incurre en subejercicios.

La falacia de la austeridad radica en que encubre el programa de ajuste estructural neoliberal, ejercitado denodadamente desde los noventa. Por la vía de los hechos se emprende la demolición sistemática de instituciones, derechos, empleos sin un acompañamiento del debate político sustancial que supere el adoctrinamiento mesiánico. ¿Cuánto podrá liberar realmente AMLO con su plan de «austeridad» mediante el recorte de 
salarios de alta burocracia y el combate a la corrupción? No hay precisión ni estudios ni informes contundentes. Además de que la embestida es contra los altos ingresos de la burocracia política, pero no los altos ingresos de los capitalistas. En esta cuestión no se mencionan los impuestos al gran capital, los paraísos fiscales y el problema de fuga de capitales. A la vez que se elude la desvalorización persistente de la fuerza de trabajo y su determinación en el deterioro de las condiciones de vida de las grandes mayorías sociales.

\section{Geopolítica del capital y desarrollo geográfico desigual}

La noción de geopolítica, como «ciencia del Estado», ha sido un área del conocimiento de índole militar — que se ha expandido a las ciencias sociales-, en aras de la expansión del poder político del Estado imperialista y del gran capital multinacional en el reparto del mundo, donde se hace una cartografía de los recursos estratégicos, naturales y humanos. En la nueva morfología del capital global, el mercado mundial y la división internacional del trabajo articulan los continentes, regiones y países a la trama de la acumulación mundial.

Para México esto significa seguir transitando por el sendero de la subordinación al capital global (Márquez, 2020). La tensión entre la soberanía nacional, el Estado nación como agente del proyecto neodesarrollista y el gran capital multinacional y el poder imperialista tiene su respuesta estratégica en la plataforma de acumulación a escalas mundial y regional.

La globalización neoliberal es una realidad para el gran capital que se expande a nivel planetario pero una ficción para los pueblos y trabajadores. 
El reparto del mundo ha sido violento (guerras mundiales, acuerdos militares y comerciales, tribunales internacionales, etcétera). Estados Unidos es la superpotencia, el imperio, que gestiona el sistema mundial con sus aliados mediante controles geopolíticos, no por medio de la oferta y la demanda o el libre mercado ni por desmesuras unipersonales (Trump, Bush). Hay un pensamiento pragmático y la proyección de grandes intereses. No obstante, para pensadores como Chomsky: «El sueño americano está muerto».

Pero seguimos presos en la «jaula de oro» (Álvarez, 2018) de un bloque económico norteamericano, comandado por el capital y el Estado estadounidenses, bajo la figura del TLCAN (o acuerdo comercial); el gran simulacro de una sociedad para el desarrollo. Para los gobiernos subordinados de la alternancia electoral mexicana ha sido una plataforma de gobierno y AMLO la retoma con regocijo: «Está a salvo nuestra soberanía», al calor de las recientes negociaciones (López, 27 de agosto de 2018). Los instrumentos como el TLCAN/T-MEC son funcionales a una acumulación regional mediante redes de capital ampliadas con sus cadenas de proveeduría y el consecuente desmantelamiento de cadenas de producción y mercado interno. En este ámbito, México funge como reserva estratégica demográfica y laboral, además de recursos naturales, para las economías de Estados Unidos y Canadá. El Estado nación es compenetrado por corporaciones multinacionales, en conjunción con las nacionales.

En el fondo, se abona a la perpetuación del imperialismo y neodependencia. Sin decirlo, se asume el poder del imperialismo y del capital transnacional como una cosa dada, inamovible, una fatalidad histórica, a la que hay que plegarse y mejor recluirse en los asuntos internos: «La mejor política exterior es la política interior» (Zavala, 31 de agosto de 2018). Se profundiza la subordinación a los intereses geopolíticos de Estados 
Unidos y continúa la desconexión con Centro, Sudamérica y el Caribe. Asumir las determinaciones del gobierno estadounidense dando continuidad al mismo patrón de subordinación económica y seguir promoviendo a México como «un paraíso para la inversión privada» (Solís, 1 de julio de 2018). El TLCAN, columna vertebral de la subordinación del patrón de acumulación, simplemente cambia de nombre, a contentillo de Trump, renombrado USMCA o T-MEC.

En esa trama se anuncia a México como un "paraíso para la inversión» con la «libertad empresarial» como premisa. El TLCAN (T-MEC) es el eje de la continuidad del esquema de integración asimétrica en una división internacional del trabajo adversa. En tanto que las zonas económicas especiales son el especio de alojamiento de los megaproyectos extractivistas e infraestructurales. La contención del flujo migratorio centroamericano refuerza el papel de guardián del perímetro de seguridad estadounidense. Las relaciones internacionales se reducen a la vecindad subordinada con el vecino del norte. La Alianza para el Progreso (Alpro) asume nueva denominación con el corredor transístmico y las «cortinas» del desarrollo son dispositivos para la contención de la migración centroamericana: papel funcional al proyecto de seguridad nacional de Estados Unidos sin atender las causas estructurales de las migraciones.

Si el TLCAN era el sello distintivo del neoliberalismo priista, su continuidad bajo las siglas del T-MEC lo serán del neoliberalismo morenista, cuyo fundamento es la configuración de una plataforma exportadora desde México, que acoge a la industria estadounidense deslocalizada, especialmente la automotriz, electrónica y aeroespacial, para aprovechar la fuerza de trabajo abundante, desorganizada y barata; paradójicamente es el único caso en el mundo donde un tratado de «libre comercio» está dividido 
por un muro fronterizo que impide el libre tránsito de las personas, especialmente de los trabajadores, la mayoría de los cuales tiene que cruzar clandestinamente, lo cual redunda en una mayor precarización y superexplotación allende las fronteras.

También se hace remembranza de la Alpro (1961-1970), proyecto de Estados Unidos, encabezado por John F. Kennedy, y se sugiere la «cooperación para el desarrollo» con aquel país. Antes, Harry Truman (1945-1953) donde algunos analistas cifran el comienzo del proyecto de desarrollo, para contrarrestar la influencia del comunismo.

De ahí que pensadores como Samir Amin recomendaran la «desconexión» de los países subdesarrollados de la globalización, pero en este caso se puede adoptar la premisa a una desconexión de un tratado comercial expoliador y una reinserción al mercado mundial en conjunción con otras regiones, como América Latina, donde México ha quedado a deber.

México funge como un país «subimperialista» (Marini, 1985), en la medida en que siendo subordinado a un poder imperial inconmensurable, como lo es Estados Unidos, a su vez, tiene la capacidad de desplegar su propia red de poder económico y geopolítico hacia zonas periféricas colindantes. Dispone de capitales multinacionales que exportan excedentes hacia Centroamérica y el Cono Sur, inclusive a regiones de Estados Unidos, y realizan inversiones en diversos ramos de la industria, el comercio y los servicios; al tiempo que el gobierno mexicano ejerce funciones militares de seguridad según los requerimientos del país hegemón del norte, sobre todo en su frontera sur, en materia de migración, narcotráfico y terrorismo, además de que tiene un cierto influjo político-cultural en América Latina, liderazgo que se ha menguado por el inactivismo político-diplomático de la 4T. 


\section{Neocolonialismo interno: megaproyectos}

El bloque económico de América del Norte (TLCAN/T-MEC, Iniciativa Mérida, etcétera) es un instrumento geopolítico de subsunción de la economía y sociedad mexicanas, una capitulación de la soberanía ante el poder capitalista estadounidense. Bajo esa rúbrica, México seguirá ubicado en el eslabón más débil de la cadena de las redes globales de capital monopolista, como proveedor de materias primas, energía y fuerza de trabajo barata. Por esa vía se organiza la transferencia de excedente, lo cual redunda en una desacumulación secular y la cancelación de cualquier proyecto de desarrollo autónomo.

En esa tesitura se da continuidad de las zonas NAFTA, es decir, los enclaves económicos de maquiladoras, extractivismo minero, energético, hidráulico y hotelero. Al respecto, la columna vertebral de la producción, inscrita en la división internacional del trabajo, ha sido la maquilización, es decir, la explotación de fuerza de trabajo barata. Dentro de las cadenas de valor global y arbitraje laboral, México funge como el eslabón más débil, merced a la política de «competitividad espuria»: la fuerza de trabajo como fundamento. Por lo mismo, se promueve ahora la ampliación de las zonas económicas especiales (ZEE), de la cuales operan siete ZEE en el país, sean declaradas o elegibles en la zona sur-sureste (Banxico, 2018). Las zonas económicas especiales representan economías de enclave exportador, una suerte de «estado de excepción económico» donde no rigen las leyes nacionales sino las normas de las corporaciones, dentro de un régimen especial de «libre mercado». El antecedente es el malogrado Plan Puebla Panamá y el ALCA, proyectos neocoloniales, una avanzada hacia la reconquista de Mesoamérica y su corredor transístmico. Ahora se resucita con 
la iniciativa denominada «cortinas del desarrollo», es decir, una política de contención del flujo migratorio centroamericano y la ocupación de fuerza de trabajo barata que proviene de esa estampida migratoria. En ese esquema operaría el Corredor Multimodal Interoceánico, un cruce del istmo entre Coatzacoalcos, Veracruz, y Salina Cruz, Oaxaca. Aunque, en realidad, lo único que ha contenido a la migración centroamericana es la fuerza de la Guardia Nacional, a instancias del gobierno de Donald Trump.

Los megaproyectos y las zonas económicas especiales preservan, aunque sin admitirlo, el modelo basado en la ventaja comparativa espuria: la explotación de fuerza de trabajo barato y el saqueo de recursos naturales. Significan, además, una actualización del colonialismo interno (Lucio, 2016). Ante el diagnóstico de la falta de crecimiento, el lopezobradorismo hace una reconsideración de los megaproyectos, otrora destructivos, ahora necesarios. La reconversión del despojo territorial al desarrollo entraña la resignificación discursiva de los megaproyectos, otrora depredadores, que se tornan necesarios, «con rostro humano»: sean turísticos o extractivos. Para legitimarlos se implementan «consultas» populares a modo para decidir o respaldar favorablemente los proyectos gubernamentales. Estas consultas tienen todo tipo de inconsistencias y terminan por ser un instrumento que pervierte la democracia participativa y clausura otras políticas de este tipo como formas genuinas de construcción de poder popular y de intervención social en las políticas públicas de largo alcance.

Frente a la nueva oleada neocolonialista no se ha generado una barrera de contención, no hay una propuesta de planificación del desarrolo nacional ni un proyecto articulador del mercado interno, de las regiones, ni un proyecto de industrialización sustentado con procesos de innovación científico-tecnológica capaz de propiciar una inserción no 
subordinada en la división internacional del trabajo. En contrapartida, la gestión inercial ahonda la segregación o balcanización del Estado nación: la geografía mexicana es barroca, contrahecha, intrincada, formada por enclaves económicos en manos de grandes capitales, junto al dominio territorial de grupos armados paramilitares y criminales, la emergencia de municipios autónomos, y las diferenciaciones regionales: zonas de exportación industrial, zonas de recursos naturales, zonas en conflicto. Frente al creciente poder de las Fuerzas Armadas del gobierno federal, persisten ejércitos privados de las organizaciones criminales, como el llamado cártel de Sinaloa, los Zetas, Cartel Jalisco Nueva Generación, la Familia Michoacana. Esto sin considerar que el Estado nación mexicano es un Estado plurinacional, que contiene al menos 60 naciones, que no son lenguas, sino naciones, además de una multidiversidad ambiental y una gran diversidad cultural, social y política, irreductibles a una sola voz, un solo partido, un solo caudillo.

Para la 4T se dibujan dos regiones privilegiadas: a) la zona norte fronteriza, el corredor maquiladora subordinado a la industria estadounidense, a la cual se le otorgan privilegios para operación del capital como disminución de impuestos, disminución de tarifas en servicios públicos y gasolina, con una leve compensación mediante el incremento al salario mínimo; y b) el sur-sureste, la zona de influencia del presidente, su querencia natural, como zona de desarrollo preferente en proyectos «estratégicos»: Tren Maya, plantación de árboles, corredor transístmico, etcétera. Esta bifurcación geográfica deja un enorme vacío, una amplia zona gris intermedia, donde sólo sobresale la joya de la corona, la Ciudad de México, que es el bastión del lopezobradorismo y el gran trampolín político para todos los efectos prácticos de la política pragmática y centralista. 


\section{Colofón: parte de guerra o el militarismo como plataforma de operación}

Existe la idea de que el neoliberalismo adelgaza al Estado, pero sólo se refiere a la disminución de la propiedad pública, pero persiste el poder del Estado y su división ejecutiva, legislativa y judicial, además de las Fuerzas Armadas. En todo caso se adelgaza para reorganizar y fortalecer.

Con la noción reduccionista de Estado como «violencia legítima»se puede incurrir en el error de acotarla a la esfera de las Fuerzas Armadas. Aún cuando hay experiencias históricas de gobiernos militares, actualmente en el mundo hay 31 países que no tienen Ejército, pero son Estados, con la peculiaridad de que casi todos fungen como paraísos fiscales —entre otros, Costa Rica, Panamá, Haití, incluso El Vaticano.

No obstante, el militarismo se refiere a un gobierno civil que atribuye funciones desproporcionadas a las Fuerzas Armadas, las que le son propias como la violencia legal y con ello las tareas de defensa ante enemigos externos y la coerción a grupos internos, pero además funciones en la administración pública y los negocios. En esa lógica, AMLO le confiere más poder a las Fuerzas Armadas: amplía ámbito de competencia, presupuesto y además le confiere un halo doctrinal como ejército del «pueblo». Por ello quiere reciclarlo, limpiarle el rostro y refuncionalizarlo como soporte del régimen de gobierno en ciernes, donde el Estado aparece como una megainstitución supresora del conflicto social, de la lucha de clases, mediante la imposición de la violencia «legítima» por vía de la fuerza pública (Ejército, Policía) y la ley (constitución, cárcel, castigo).

Un pilar de la 4T es la profundización de la militarización, que había sido cuestionada cuando era oposición. Si bien el adagio latino dice: «si 
quieres la paz, prepárate para la guerra», cabe la posibilidad de que un Estado obrero se prepare para defenderse del Estado burgués derrocado, pero en México no es el caso. Se presagia la continuidad del modelo económico-político y el reforzamiento de la militarización se inscribe en la guerra de cuarta generación (contra el narco) y la defensa del modelo económico. El Ejército en México está muy desacreditado, porque ha sido usado para reprimir, violentar, desaparecer y proteger al régimen político. Además de que ha estado coludido en la economía criminal de las drogas y la espiral de violencia asociada. Esta misma institución pretende ser empoderada mediante el incremento de las partidas presupuestales y la formación de la Guardia Nacional, que a diferencia del modelo europeo (policial) y el modelo estadounidense (reserva miliar) persigue un modelo de policía militarizada con mando del Ejército (o, civil, haciendo una concesión), mediante el despliegue de labores policiales con rango constitucional para tomar el control del territorio e implementar la política de seguridad nacional.

En un país plagado de conflictos sociales por la resistencia contra los megaproyectos, la existencia de autodefensas y policías comunitarias, comunidades indígenas autónomas, territorios zapatistas y focos guerrilleros (Castellanos, 2018), con un incremento sustancial del presupuesto se da continuidad a la política de «guerra contra las drogas» por lo que hace a la militarización, el populismo punitivo, sin tocar el nervio financiero de la economía criminal. El Ejército es presentado como una fuerza de paz, cuando históricamente ha sido una fuerza represiva del Estado contra el pueblo, estudiantes, campesinos, indígenas, se ha involucrado en terrorismo de Estado, la matanza de 1968, 71, la «guerra sucia», Aguas Blancas, Ayotzinapa, Tlataya y vínculos con el narcotráfico. 
Los militares tienen adiestramiento, disciplina e ideología para la represión no para la prevención; en ello han sido entrenados por militares de Estados Unidos, Israel y Europa; hay un riesgo de que la policía militar realice funciones de seguridad pública, para la que no están formados, incluso en migración.

Se trata de una «violencia organizada», irreductible a los «cárteles de la droga» $\mathrm{o}$ «narcotraficantes», puesto que existe un capital criminal integrado por el Estado, corporaciones empresariales, grupos paraestatales y grupos criminales (Márquez, 2020). La «guerra irregular» atiende a la doctrina conjunta estadounidense: «Una lucha violenta entre actores estatales y no estatales por la legitimidad e influencia sobre poblaciones relevantes», guerra de cuarta generación (control de los medios de comunicación, las redes informáticas físicas y digitales). El objetivo es el político de la población (Pisano, 2010). Más que soluciones de fuerza (militarización, populismo punitivo) debe entenderse cómo se configura socialmente lo que se denomina delito y actuar sobre las estructuras sociales que lo detonan.

El populismo punitivo es otro rasgo de continuidad con la lógica de militarización. Al propio Ejército se le confieren facultades extraordinarias: agente inmobiliario, administrador del nuevo aeropuerto de Santa Lucía. Evidentemente, AMLO pretende agenciarse el apoyo de las Fuerzas Armadas, y eventualmente eludir un golpe de Estado, pero a costa de empoderar al Ejército, que ha sido una fuerza represiva contra movimientos sociales, líderes sociales, comunidades, estudiantes, y ha estado involucrada en contrainsurgencia y la economía criminal, y no un «Ejército del pueblo», «el pueblo uniformado», como pretende AMLO.

El Ejército es omnipresente en la 4T y tiene nuevas funciones asignadas. Ahora cumplen tareas de policías con la formación de la Guardia Nacional, 
el plan contra el «huachicol» o robo de hidrocarburos y la contención del flujo migratorio en las fronteras sur y norte; también se desempeñan como constructores del aeropuerto internacional Felipe Ángeles en Santa Lucía y la construcción de 2 mil 700 sucursales del Banco del Bienestar; serán sembradores en el programa Sembrando Vida con la producción y siembra de árboles, además de que participan en el programa Jóvenes Construyendo el Futuro. Sin embargo, el Ejército ha fungido como fuerza contrainsurgente, estuvo vinculado en la desaparición de los 43 estudiantes normalistas de Ayotzinapa, Guerrero.

El gobierno de la $4 \mathrm{~T}$ propone subir sustancialmente el presupuesto asignado a las fuerza militares y policiacas, reforzando el carácter de Estado-policía. Propone que las tres dependencias federales con tareas de seguridad - Secretaría de la Defensa Nacional (Sedena), la Secretaría de la Marina (Semar) y la Secretaría de Seguridad y Protección Ciudadana (SSPC) — dispongan de 186 mil 773 millones de pesos. Las prioridades presupuestales de la 4T para 2020 están en Pemex (86 mil millones de pesos como parte de un programa de «rescate»), bienestar social y seguridad.

La agenda de seguridad regional es una disposición geopolítica de alcance regional comandada por Estados Unidos, adscrita a su política hegemónica, militar, política y diplomática, que ha desplegado diversas instituciones, políticas, programas y presupuestos. Desde organismos interventores como la DEA, programas como la Iniciativa Mérida, políticas extraterritoriales como la llamada guerra contra las drogas y la promoción en terceros países, como México, de la militarización de la policía civil, como la formación de la Guardia Nacional, la modificación de la ley, como el Código Penal y otras normas legales y campañas como la contención de la migración de centroamericanos. 


\section{Referencias}

Álvarez, A. (2018). Cómo el neoliberalismo enjauló a México. El contexto de los siglos XX y XXI y la alternativa de un ecosocialismo democrático. México: Universidad Nacional Autónoma de México.

Banco de México (2018). «Las zonas económicas especiales de México». Recuperado de http://www.banxico.org.mx/publicaciones-y-prensa/reportessobre-las-economias-regionales/recuadros/\%7B20867F6A-F174-04D0-9A04BB846DB7EFC3\%7D.pdf

Banco Mundial (2020). «Covid-19 financial access development policy financing». Recuperado de http://documentsl.worldbank.org/curated/en/ 346641590199324465/pdf/Mexico-COVID-19-Financial-Access-DevelopmentPolicy-Financing-Program.pdf

Barranco, B. y Blancarte, R. (2019). AMLO y la religión. El Estado laico bajo amenaza. México: Grijalbo.

Blyth, M. (2014). Austeridad. Historia de una idea peligrosa. Barcelona: Crítica. Bresser, L.C. (2010). Globalización y competencia. Buenos Aires: Siglo XXI.

Centro de Análisis Multidisciplinario (2018). «Reporte especial 131: Lo que el gobierno de AMLO no dice al usar nuestras cifras sobre el poder adquisitivo del salario. Nada cambia por decreto». Universidad Nacional Autónoma de México.

Castellanos, L. (2018). Crónicas de un país embozado: 1994-2018. México: Era.

Ceceña, A.E. (2019). «Geopolítica del Tren Maya». En VV.AA., Impactos sociales y territoriales del Tren Maya. Miradas multidisciplinarias. México: Instituto Nacional de Antropología e Historia/Universidad Autónoma Metropolitana. 
Chávez, V. (14 de abril de 2019). «Reforma laboral pondrá fin a la extorsión de 〈líderes charros): Delgado». El Financiero. Recuperado de https://www. elfinanciero.com.mx/nacional/reforma-laboral-pondra-fin-a-extorsion -de-lideres-charros-delgado

Dussel, E. (2006). 20 tesis de política. México: Siglo XXI.

Expansión (2019). «Las 500 empresas más importantes de México». Recuperado de https://expansion.mx/empresas/2019/06/28/estas-son-las-500-empresas -mas-importantes-de-mexico-2019

Farfán, G. (2011). «La economía política del Estado rentista mexicano (19702010)». Foro Internacional, LI(3).

FondoNacionaldeFomentoalTurismo(Fonatur)(13defebrerode2019).«ElTrenMaya presenta modelo financiero». Gobierno de México. Recuperado de https:// www.gob.mx/fonatur/prensa/el-tren-maya-presenta-modelo-financiero

Forbes (12 de marzo de 2020). «El mercado se regula con el mercado, afirma AMLO ante contexto de crisis». Recuperado de https://www.forbes.com. $\mathrm{mx} /$ politica-mercado-regula-con-mercado-amlo-contexto-crisis/

Frank, A.G. (1972). Lumpenburguesía: Lumpendesarrollo. Dependencia, clase y política en América Latina. Buenos Aires: Ediciones Periferia.

Gómez, N. (14 de febrero de 2019). «Nace la Confederación Internacional de Trabajadores». La Jornada. Recuperado de https://www.jornada.com.mx/ 2019/02/14/opinion/010alpol

González, R. (21 de octubre de 2019). «La distribución del ingreso, la más desigual de la historia». La Jornada. Recuperado de https://www.jornada.com. $\mathrm{mx} / 2019 / 10 / 21 /$ economia/025nleco

Instituto Nacional de Estadística, Geografía e Informática (INEGI) (2020). Encuesta Nacional de Ocupación y Empleo. Aguascalientes: Instituto Nacional de Estadística, Geografía e Informática. 
Katz, C. (2015). «¿Qué es el neodesarrollismo? Una visión crítica. Argentina y Brasil». Serviçio Social \& Sociedade (122).

López, A. (2007). La mafia nos robó la presidencia. México: Grijalbo.

López, A. (15 de mayo de 2020). «La nueva política económica en los tiempos de coronavirus».

López, A. (17 de marzo de 2019). «Presidente López Obrador declara formalmente fin del modelo neoliberal y su política económica». Gobierno de México. Recuperado de https://www.gob.mx/presidencia/prensa/presidentelopez-obrador-declara-formalmente-fin-del-modelo-neoliberal-y-supolitica-economica-lo-que-hagamos-sera-inspiracion-para-otros-pueblos

López, A. (2017). 2018 La salida. Decadencia y renacimiento de México. México: Planeta.

López, A. (22 de septiembre de 2020). «Mensaje del presidente Andrés Manuel López Obrador durante el Debate de la Asamblea General de las Naciones Unidas». Gobierno de México. Recuperado de https://www.gob.mx/ presidencia/prensa/mensaje-del-presidente-andres-manuel-lopez-obradordurante-el-debate-de-la-asamblea-general-de-las-naciones-unidas?idiom=es López, A. (27 de agosto de 2018). «Celebra AMLO que quede a salvo soberanía de México durante renegociación del TLC». Recuperado de https:// lopezobrador.org.mx/2018/08/27/celebra-amlo-queda-a-salvo-soberaniade-mexico-durante-renegociacion-del-tlc/

Lucio, C. (2016). Conflictos socioambientales, derechos humanos y movimiento indígena en el Istmo de Tehuantepec. México: Universidad Autónoma de Zacatecas.

Marini, R.M. (1985). Subdesarrollo y revolución. México: Siglo XXI.

Márquez, H. (2018). «Votaciones en México 2018: la trama del teatro electoral o la reproducción del sistema de poder». Observatorio del Desarrollo, 7(20). 
Márquez, H. (2018a). «El vértigo transformista. Antinomias del lopezobradorismo en México». Observatorio del Desarrollo, 7(21).

Márquez, H. (2018b). «Pensar la política desde la práctica. Falacias de la democracia y pertinencia de la emancipación». Estudios Críticos del Desarrollo, VIII(14).

Márquez, H. (2018c): «Modelo para desarmar: acumulación por superexplotación y despojo en México». Observatorio del Desarrollo, 7(19).

Márquez, H. (2018d). «Distopía neoliberal en México. Trama sociopolítica del poder y resistencia social». Observatorio del Desarrollo, 7(20).

Márquez, H. (2020). «El capital es el crimen organizado: violencia, mercancía ilícita y dinero negro». En Esquivel, S., Martínez, L. y Hernández, J. (coords.), Textos y contextos psicosociales. Violencia, pobreza y género. Querétaro: Consejo de Ciencia y Tecnología del Estado de Querétaro.

Márquez, H. (2020). «Pautas de la subordinación de México al capital global. Noticias de la antigüedad ideológica o novedades de la dependencia». En Tetreault, D. y Chávez, M. (coords.), Rostros del desarrollo neoliberal en México. México: Miguel Ángel Porrúa/Universidad Autónoma de Zacatecas.

Marx, K. (2003). El dieciocho brumario de Luis Bonaparte. Madrid: Alianza Editorial.

Muñoz, A. y Urrutia, A. (29 de enero de 2020). «Se enfocará Romo en eliminar trabas burocráticas para captar inversión». La Jornada. Recuperado de https://www.jornada.com.mx/Últimas/politica/2020/01/29/se-enfocararomo-en-eliminar-trabas-burocraticas-para-captar-inversion-5713.html

Notimex (14 de mayo de 2019). «Por corrupción, México pierde hasta 10\% del PIB: Función Pública». El Economista. Recuperado de https://www. eleconomista.com.mx/politica/Por-corrupcion-Mexico-pierde-hasta-el10-del-PIB-Funcion-Publica-20190514-0066.html 
Organización para la Cooperación y el Desarrollo Económicos (OCDE) (2018). A broken social elevator? How to promote social mobility. Paris: Organización para la Cooperación y el Desarrollo Económicos.

Organización para la Cooperación y el Desarrollo Económicos (2020). «Hours worked». Recuperado de https://data.oecd.org/emp/hours-worked.htm

Ortiz, A. (1998). El desarrollo estabilizador. Reflexiones sobre una época. México: Fondo de Cultura Económica/El Colegio de México

Paredes, S. y Ávila, Y. (4 de abril de 2018). «¿La corrupción cuesta 9\% del PIB en México». Recuperado de https://verificado.mx/corrupcion-cuesta-pib/

Pisano, D. (2010). «México neoliberal y la guerra de cuarta generación». Recuperado de https://filosofiamexicana.files.wordpress.com/2010/09/davidpisano-mexico-neoliberal-y-la-guerra-de-cuarta-generacion.pdf

Aristegui Noticias (12 de marzo de 2020). "Plantea AMLO a Banxico no intervenir en el mercado para fortalecer al peso». Recuperado de https:// aristeguinoticias.com/1203/mexico/plantea-amlo-a-banxico-no-interveniren-el-mercado-para-fortalecer-al-peso-enterate/

El Financiero (13 de marzo de 2020). «Banorte, la mejor opción en el mercado de las remesas este año: AMLO». Recuperado de https://www. elfinanciero.com.mx/economia/banorte-la-mejor-opcion-en-el-mercado -de-las-remesas-este-ano-amlo

Secretaría de Gobernación (Segob) (2 de abril de 2020). «Decreto por el que se ordena la extinción o terminación de los fideicomisos públicos, mandatos públicos y análogos». Recuperado de https://www.dof.gob.mx/nota_detalle.php?codigo $=5591085 \&$ fecha $=02 / 04 / 2020$

Secretaría de Gobernación (Segob) (17 de mayo de 2019). «Decreto por el que se crea el Consejo Nacional para el Fomento a la Inversión, el Empleo y Creci- 
miento Económico». Diario Oficial de la Federación. Recuperado de https:// www.dof.gob.mx/nota_detalle.php?codigo $=5560667 \&$ fecha=17/05/2019

Secretaría de Hacienda y Crédito Público (SHCP) (2020). «Situación económica, finanzas públicas y deuda pública al segundo trimestre de 2020».

Sin Embargo (1 de julio de 2019). «Los primeros 6 meses de AMLO, más de 11,000 funcionarios denuncian que han firmado su «renuncia»». Sin Embargo. Recuperado de https://www.sinembargo.mx/01-07-2019/3605485

Solís, A. (1 de julio de 2018). «México tendrá que ser un paraíso de inversión: Romo». Forbes México. Recuperado de https://www.forbes.com.mx/mexico -tendra-que-ser-un-paraiso-de-inversion-alfonso-romo/

Stuckler, D. y Basu, S. (2013). Por qué la austeridad mata. El costo humano de las políticas de recorte. México: Taurus.

Torres, J. (2017). «El corredor del Istmo de Tehuantepec: de los proyectos fallidos a las nuevas posibilidades para su desarrollo». Espacios Públicos, 20(48).

Torruco, M. (14 de agosto de 2018). Recuperado de https://twitter.com/ TorrucoTurismo/status/1029342248075321344

Vázquez, D., Delgado, M. y Jaramillo, M. (2018). México justo: propuestas de políticas públicas para combatir la desigualdad. México: Oxfam.

Williamson, J. (editor) (1990). Latin American adjustment: how much has happened. Washington: Peterson Institute for International Economics.

Zavala, M. (31 de agosto de 2018). «México será neutral ante conflictos en el extranjero, dice AMLO». El Universal. Recuperado de https://www. eluniversal.com.mx/nacion/politica/mexico-sera-neutral-ante-conflictos -en-en-el-extranjero-dice-amlo 